$N$

Global Journals In

(3)

\title{
Diversity of Butterflies (Lepidoptera: Rhopalocera) of Jhargram, Paschim and Purba Medinipur Districts, West Bengal, India
}

By Saurav Dwari \& Amal Kumar Mondal

Vidyasagar University

Abstract-Butterflies are one of the most attractive insects in the world, and they have been able to attract all kinds of peoples by their various features. This present documentation records the butterfly diversity of the three districts Jhargram, Paschim Medinipur, and Purba Medinipur, which formed the former Medinipur district. A total of 139 species belong to 94 genera and six families have been recorded. Among all families, Lycaenidae and Nymphalidae are the most abundant. Among the three districts, most species were found from Jhargram district. Fluffy Tit, Angled Pierrot and Common Lascar are the first time recorded from southern West Bengal. Rapid urbanization, deforestation, uncontrolled developmental works, and changing the character of Coastal zone is some of the threats to butterflies in these areas. So it was a great need to prepare a list of butterflies by which the past changes in the species diversity and number of butterflies in the future able to understand.

Keywords: butterflies, jhargram, paschim medinipur, purba medinipur, west bengal, india, lycaenidae, nymphalidae, urbanization, deforestation.

GJSFR-C Classification: FOR Code: 270499

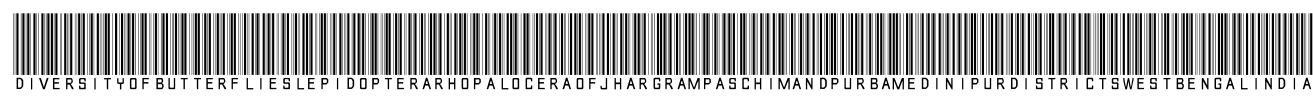

Strictly as per the compliance and regulations of:

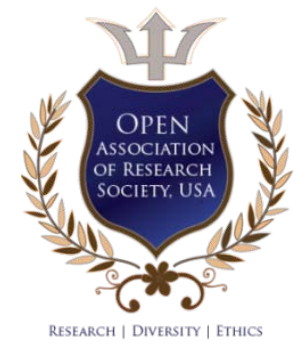

(c) 2020. Saurav Dwari \& Amal Kumar Mondal. This is a research/review paper, distributed under the terms of the Creative Commons Attribution-Noncommercial 3.0 Unported License http://creativecommons.org/licenses/by-nc/3.0/), permitting all non commercial use, distribution, and reproduction in any medium, provided the original work is properly cited. 


\title{
Diversity of Butterflies (Lepidoptera: Rhopalocera) of Jhargram, Paschim and Purba Medinipur Districts, West Bengal, India
}

\author{
Saurav Dwari ${ }^{\alpha} \&$ Amal Kumar Mondal ${ }^{\sigma}$
}

Abstract-Butterflies are one of the most attractive insects in the world, and they have been able to attract all kinds of peoples by their various features. This present documentation records the butterfly diversity of the three districts Jhargram, Paschim Medinipur, and Purba Medinipur, which formed the former Medinipur district. A total of 139 species belong to 94 genera and six families have been recorded. Among all families, Lycaenidae and Nymphalidae are the most abundant. Among the three districts, most species were found from Jhargram district. Fluffy Tit, Angled Pierrot and Common Lascar are the first time recorded from southern West Bengal. Rapid urbanization, deforestation, uncontrolled developmental works, and changing the character of Coastal zone is some of the threats to butterflies in these areas. So it was a great need to prepare a list of butterflies by which the past changes in the species diversity and number of butterflies in the future able to understand.

Keywords: butterflies, jhargram, paschim medinipur, purba medinipur, west bengal, india, lycaenidae, nymphalidae, urbanization, deforestation.

\section{INTRODUCTION}

nsects has major contributors in the world biodiversity basically more than half of the world's species diversity and play an important role in maintaining the productivity and stability of the entire ecosystem [1, 2, 3, 4]. Butterflies are pollinators, food chain components as well as indicators of the health of the ecosystem, it is essential to identify them and prepare a list and protect their larval host plants and habitat $[5,6]$. Butterflies help maintain the community structure of the flora of the tropical region [7]. Due to the decaying quality of butterflies' natural habitat and urbanization, the diversity and number of species are gradually declining $[8,9,10$, 11]. Butterfly research in India started in the nineteenth century with the assistance of various researchers [12]. Mega diversity country like India has also large depositary in respect of butterflies which is about one fifth in the World biodiversity respect [13]. In India 1501 species of butterflies recoded $[13,14,15]$ however some have mentioned 1318 species in the Indian subcontinent [16]. Many researchers explored the diversity of butterflies in various parts of India [17, 18,

Author a $\sigma$ : Plant Taxonomy, Biosystematics and Molecular Taxonomy Laboratory, UGC-DRS-SAP Department, Department of Botany \& Forestry, Vidyasagar University, Midnapore-721 102, West Bengal, India.e-mails: saurav.dwari@gmail.com, amalcaebotvu@gmail.com
$19,20,21,22]$. A decent number of investigates on butterflies got from different places of West Bengal. The state West Bengal archived four hundred fifty-two species [23], although a researcher has likewise referenced 330 species [24]. Butterfly research in West Bengal is nearly contemporary with India, different analysts at various occasions propelling butterfly study of the southern division of this state $[25,26,27,28,29$, $30,31]$. Major research on butterflies found from Purba Medinipur among three districts of study area [32, 33, 34]. A unique field study from Paschim Medinipur district point outs that 82 species of butterflies present in the urban area of Midnapore [7]. In any case, no past exploration obtained from the immense locale outside the urban area of Paschim Medinipur and entire Jhargram District. Nonetheless, due to differing territory and rich forest area and being part of Chotanagpur plateau, there is a great chance of new species being encountered, that were not earlier found in South Bengal [35]. Documentation was comprehending the adjustments in the diversity and quantities of butterflies as anthropogenic movements expanded, and forest cover diminished. In the past, Jhargram, Paschim, and Purba Medinipur were part of undivided Medinipur district, so Purba Medinipur additionally incorporated for the survey alongside the other two districts.

\section{il. Material and Methods}

\section{a) Study area}

Jhargram, Paschim Medinipur and Purba Medinipur, located in the south-west of West Bengal, have been formed by breaking up the former Medinipur district at different times (Fig.1). Medinipur district first divided into Paschim and Purba Medinipur in 2002. Later in 2017, the Jhargram district was formed by separating from the Paschim Medinipur district. In other words, the three places of the study area were one district in the past. Headquarter of Jhargram lies at $21.4550^{\circ} \mathrm{N}$ latitude, and $86.9974^{\circ} \mathrm{E}$ longitude and the district covers $3037.64 \mathrm{~km}^{2}$. Headquarter of Paschim Medinipur lies at $22.4257^{\circ} \mathrm{N}$ latitude, and $87.3199^{\circ} \mathrm{E}$ longitude and the district covers $6308 \mathrm{~km}^{2}$. Headquarter of Purba Medinipur lies at $22.2858^{\circ} \mathrm{N}$ latitude, and $87.9189^{\circ} \mathrm{E}$ longitude and the district covers $4736 \mathrm{~km}^{2}$. Jhargram district is deceit between the Kangsabati River 
in the north and the Subarnarekha River in the south. This district surrounded by Paschim Medinipur, Bankura, Purulia districts, and Odisha, Jharkhand states. Jhargram, Purba Medinipur, Bankura, Hoogly, Howrah districts, and Odisha states surrounded Paschim Medinipur district. Paschim Medinipur, Howrah districts, and Odisha state surrounded Purba Medinipur district. Purba Medinipur is bounded on the south by the Bay of Bengal, on the east by the river Hoogly and the northeast by the Rupnarayan River. Jhargram district is a part of Chotanagpur Plateau, which steadily slopes down on the way to the east. The altitude of the Kankrajhore area of this district is near about 300 meters. The average rainfall of this district is about $1400 \mathrm{~mm}$. This district is full of dry deciduous forests, which are the home of diverse life forms. Paschim

Medinipur is one of the largest districts of the state, West Bengal. Western parts of this district are part of Chotanagpur Plateau and packed with lateritic soils. The landscape of this district modifies from dense, dry deciduous forests in the west to marshy wetlands in the east with an alluvial type of soil. The average rainfall of this district is about $2111 \mathrm{~mm}$. Purba Medinipur district is part of lower Gangetic and eastern coastal plains. This district has approximately $60 \mathrm{~km}$ coastline, which is about $27 \%$ of the shoreline of West Bengal. The average rainfall of this district is about $1700 \mathrm{~mm}$. The different natural habitats within the study area are also represented (Fig.2).

\section{b) Sampling techniques and species identification}

Diverse habitats of these districts have been surveyed from 2014 to 2019 through the Pollard's line transect method. Different information about butterflies collected through observation from 7 am to $11 \mathrm{am}$ and from $2 \mathrm{pm}$ to $6 \mathrm{pm}$. Transects were walked once a month in each district to follow Pollard Walk Method for documenting the butterflies [36, 37]. A slow 180-degree visual sweep carried out during walking. Along with that, Visual encounter assessment and Opportunistic survey, methods are also applied during the study period. Modifications of the line transect count used to find out butterfly richness and abundance [38]. In this method 10 permanent 300 meter lines transects were arrangement in each districts. Transects in every group was slowly crossed at a consistent speed during excellent weather period (no heavy rain or strong winds). Butterfly species recorded approximately a radius of five-meters from the observer covering either side, above, and front. All individuals were identified in the field using standard guides and field guide books [23, $39,40]$. Identification and classification of butterflies completed with these literature [41, 42, 43, 44, 45].

c) Data analysis

Data analyses were done through PAST software Version 3.02 [46].

\section{i. Measurement of diversity}

The kind of diversity used here is $\alpha$-diversity, which is the diversity of species within a community or habitat. We calculated the diversity index by using this index [47].

- Diversity index $=\mathrm{H}=-\Sigma \mathrm{Pi} \ln \mathrm{Pi}$, where $\mathrm{Pi}=\mathrm{S} / \mathrm{N}$

- $\mathrm{S}=$ numeral of entities of one species

- $\quad \mathrm{N}=$ sum total number of every individuals in the sample

- $\quad$ In = logarithm to base e

ii. Measurement of species richness index [48].

Species richness calculated through Margalef's

- Margalef's index $=(S-1) / \ln N$

- $\mathrm{S}=$ sum number of species

- $\mathrm{N}=$ summation of individuals in the sample

- $\quad$ In = natural logarithm

iii. Measurement of evenness

For calculating the evenness of species, the Pielou's Evenness Index (e) used [49].

- $\mathrm{e}=\mathrm{H} / \ln \mathrm{S}$

- $\mathrm{H}=$ Shannon - Wiener diversity index

- $\mathrm{S}=$ summation of species in the sample

iv. Dominance and Simpson Index

- $\quad D=\Sigma(n i / n)^{2}$ where ni is number of entities of taxon i.

- Dominance $=1$-Simpson index. Varies from 0 (all taxa are uniformly there) to 1 (one taxon dominates the community entirely).

- Simpson index 1-D. It calculates the 'evenness' of the community from 0 to 1 . Dominance and Simpson indices frequently used interchangeably.

\section{v. Species Accumulation Curve}

Species accumulation curve is an approach by plotting the cumulative number of species collected against the sampling effort (sample unit). From the year 2014, the species accumulation curve for the three districts sampled individually increased from first to the last sampling though the number of new species included slowly.

\section{vi. PCA (Principal Component Analysis)}

Principal components analysis (PCA) finds hypothetical variables (components) accounting for as much as possible of the variance in multivariate data $[50,51]$. Principal coordinates analysis (PCO) is a different ordination method, also known as Metric Multidimensional Scaling. Two variables were selected based on higher variance and the Eigen value scale. Density and frequency plotted as component 1, and component 2 respectively. 


\section{RESULTS}

During the study period, 139 species of 94 genera belonging to 6 families from three districts have been recorded (Table 1). Lycaenidae family is dominant among all families, followed by Nymphalidae, Hesperiidae, Pieridae, Papilionidae, and Riodinidae. 44 (31.65\%) species of Lycaenidae family, 38 (27.33\%) species of Nymphalidae, 28 (20.14\%) species of Hesperiidae, 17 (12.23\%) species of Pieridae, 11 (7.91\%) species of Papilionidae and only one species (0.71\%) of Riodinidae have been found (Fig.3). Our study shows that 66 genera represent only one species, and 28 genera represent more than one species. Junonia is the largest genus with six species followed by Papilio, Eurema, Graphium, Rapala, Spindasis, Chilades, Danaus, and Pelopidas. Depending on the availability of butterflies, 66 species categorized as very common, 38 as common, 20 as less common, eight as rare, and seven species as very rare (Fig.4). The species accumulation curve is shown in fig.5. There are some Less Common (LC) species were Crimson Rose, Spot Swordtail, White Orange Tip, Small Salmon Arab, Three Spot Grass Yellow, Large Oakblue, Grass Jewel, Black Rajah, Common Sergeant, Water Snow Flat, Moore's Ace, Forest Hopper, Conjoined Swift, Variable Swift, and Plain Palm Dart, etc. The Rare (R) species of this district were Fivebar Swordtail, One Spot Grass Yellow, Indigo Flash, Malayan, Tawny Rajah, Tricolour Pied Flat, and Golden Angle, etc. The Very Rare (VR) species of this district were Spotless Grass Yellow, Angled Sunbeam, Redspot, Fluffy Tit, Angled Pierrot, Common Nawab, and Common Lascar. Of the three districts of the study area, most species were found in Jhargram (136 species), then in Paschim Medinipur (125 species) and least in Purba Medinipur (117 species) (Fig.6). Jhargram also had the highest number of exclusive species. Restricted species of Jhargram were Spot Swordtail, Fivebar Swordtail, Spotless Grass Yellow, Angled Sunbeam, Fluffy Tit, Indigo Flash, Angled Pierrot, Malayan, Common Nawab, Tawny Rajah, Common Lascar, and Golden Angle. Restricted species of Jhargram and Paschim Medinipur were Spot Swordtail, One Spot Grass Yellow, Indian Oakblue, Large Oakblue, Purple Leaf Blue, Common Hedge Blue, Baronet, and Tricolour Pied Flat. Restricted species of Purba Medinipur were Small Salmon Arab, Redspot, and White Tiger. Measurements of diversity-related indices are represented in table 2. Principal component analysis (PCA) of butterfly of these three districts, West Bengal based on Density and Frequency data (these two variables are taken based on higher Variance and Eigen value scale) presented in fig.7, 8 \& 9. In both the cases, $\mathrm{X}$-axis (component 1), i.e. Density and on the Y-axis (component 2), i.e. Frequencies are plotted, which show similarities between different species. So, there are six different families that are separated by principal component analysis, and species are separated on PCA analysis based on these two variables. The families represented by the following colors - Papilionidae + cross red, Pieridae circle o, Lycaenidae triangle, Riodinidae square, Nymphalidae filled square, Hesperiidae filled triangle. The PCA analysis showing family Nymphalidae widely distributed among the middle of the plot represented by filled square pinkish. PCA results indicate that two families occupy larger range, family Lycaenidae is forming its range inside the family Nymphalidae, and family Pieridae ranges between Nymphalidae and Lycaenidae. This overlapping distribution might be because of the same habitat preferences and availability of host plants. In figure 10 and 11, Normal Probability distribution of Density and Frequency are presented. Figure 12 showed Matrix plot with Number, Density, and Frequency of butterfly species. Correlations of Density and Frequency of butterfly species are showing in figure 13. Fig.14. correspond to Cluster analysis of three districts viz. Jhargram (1), Paschim Medinipur (2), Purba Medinipur (3) based on various diversity indices. Observed butterfly species photographed by Canon EOS 550 D, and represented in fig.15-23.

\section{Discussions}

Among the three districts of the study area, no butterfly documentation made earlier from Jhargram district. As there is no research work on butterfly in the past, it cannot compare with the present study. However, nearly similar findings showed in previous studies of neighboring Bankura and Purulia [31, 52]. The main reason is the similarity of landscape, weather, and flora's composition of these districts. Many rare species Obtained by Mukharjee and Mondal [31] in Bankura district such as Common Shot Silverline, Tailless Lineblue, Angled Sunbeam, Gaudy baron, Painted Lady, Black Rajah, Common Nawab, Tawny Rajah, Common Banded Peacock, Spotless Grass Yellow, Indian cabbage White, Golden Angle, Water Snow Flat, and Tricoloured Pied Flat also found in Jhargram district. Some other species found in the Bankura district are likely to be found in Jhargram; they are Scarce Shot Silverline, Bright Babul Blue, Double Branded Crow, Chocolate Albatross, and Common Small Flat, etc. Some of the rare species of Purulia [52], which also found in Jhargram viz. Indigo Flash, Common Red Flash, Black Rajah, Common Nawab and Fivebar Swordtail, etc. A research has been done from earlier in Paschim Medinipur district, based on this subject mainly the urban areas adjacent to Midnapore Sadar city and recorded 82 species [7]. At present, this study has found 125 species from the entire Paschim Medinipur District. The most research on butterfly documentation has been from the Purba Medinipur district [32, 33, 34]. The primary documentation finished from the Contai 
(Kanthi) region, then the major research was done from the entire coastal area of this district and afterwards from the Haldia industrial zone. Overall 120 species recorded in these three studies from Purba Medinipur. The present status from our study reveals that about 117 species were found in entire Purba Medinipur District. Earlier in this district, Small Palm Bob (Very Rare), Giant Redeye (Very rare), Palm Redeye (Rare), Straight Swift (Common), Large branded Swift (Not Rare), Bevan's Swift (Rare) and Glassy Tiger (Very Rare) obtained by Payra et al. was not found in our present study. Small Cupid, Double Branded Crow, Bengal Spotted Flat, Small Branded Swift obtained by Pahari et al. was also not found in our study. In our current study, Redspot, Peacock Royal, Black Rajah, Gaudy Baron, Water Snow Flat, Paintbrush Swift, and Common Dartlet first time recorded from Purba Medinipur district. The documented result shows that the overall diversity of butterflies in the three districts of the study area is satisfactory. Some of these butterflies found from South Bengal for the first time. Fluffy Tit, Angled Pierrot, and Common Lascar butterflies first time recorded from South Bengal $(24,39)$. Redspot, a rare butterfly, was recorded second time from South Bengal which, was previously recorded only from Kolkata and North Bengal [53]. Some butterflies found from the coastal area of Purba Medinipur district, confined to that area only among the three districts. They are Redspot, Small Salmon Arab, and White Tiger. There are several butterflies in the elevated and forested environment of Jhargram district which are not found anywhere else in the three districts of the study area. They are Fivebar Swordtail, Spotless Grass Yellow, Angled Sunbeam, Fluffy Tit, Angled Pierrot, Common Lascar, Common Nawab, Tawny Rajah, Golden Angle, etc. The butterflies found in the coastal region of Purba Medinipur are likely to be found in the coastal region of South 24 Pargana, and the Butterflies found in Jhargram are likely to be found in Purulia, Bankura due to similar weather and geography. The butterfly diversity of a region is directly related to the larval host plants found in that region. Diversity of larval host plants of Jhargram district is more varied than the other two districts. Although most of the Paschim Medinipur similar to Jhargram district but presence of the less elevated regions, uncontrolled development work, and deforestation are the main reason of its less number of butterflies. However, the parts of Jhargram and Paschim Medinipur districts yet not illuminated in the light of such research for dense forests, inaccessibility, and political instability, which indicates the possibility of more new butterflies, will recorded in the future. Grass jewel, the smallest butterfly of India [54], found in good numbers in Jhargram and Paschim Medinipur but absent in Purba Medinipur district. Blue Mormon, the largest butterfly in South Bengal, is quite affordable in all the three districts. Small salmon Arab and White tiger are found only in the coastal areas of Purba Medinipur. The number of Crimson Rose in the coastal region is higher than in other regions. The main reason for the good sighting of Gaudy Baron in the Shal forest area is the predominance of hemiparasitic taxon like Dendropthe falcata (Loranthaceae) as the larval host plant of the butterfly in this forest. This hemiparasitic plant also used as a larval host plant by Peacock royal, Broadtail Royal, Common Jezebel, etc. Different forms of several butterflies of the same species observed in all the three districts. They are Cyrus, Stichius, Romulus of Common Mormon and Dissimilis, Clytia of Common Mime, etc. In Ghatal Sub Division, Gram Blue, Pea Blue, Forget Me Not butterflies are predominant because of the abundance of leguminous vegetables in this region. Double-banded Judy, Bamboo Treebrown, and other shade lover butterflies can be seen commonly in shady places of forest or bush areas throughout the study region. All six species of Junonia found in India are also found in the study area. However, Yellow and Chocolate Pansy were more noticeable in the red soil forest area of Jhargram and Paschim Medinipur districts. Some butterflies of The Hesperiidae family such as Golden angle, Water snow flat, Tricoloured pied flat were found more in the forest areas.

\section{Conclusion}

Our study will considered as baseline data for Jhargram and Paschim Medinipur districts, which will later help in finding out the changes of distribution, diversity of butterflies, and their possible causes in these two adjacent districts. It will also be easier to document new butterflies in these two districts using this inventory in future. In the case of the Purba Medinipur, the current study is more or less supporting the previous studies of that district. The addition of a few new butterflies that not documented from Jhargram and Paschim Medinipur districts previously indicates that there is a possibility of getting more new butterflies from these two districts in the future. At the same time, it is comprehensible that the diversity of butterflies depends on forest areas, which might be directly affected by future deforestation. Similarly, uncontrolled constructions in the coastal regions will be adversely affected bioindicators and pollinating agents like butterflies.

\section{AcKnowledgments}

Authors are especially grateful to Sourav Maiti and Kalishankar Roy, who have shared with us some extraordinary observation from Purba Medinipur that is an excellent example of citizen science. We would also like to thank Kalyan Mukherjee, Asim Giri, Aniruddha Singhamahapatra, Saptarshi Goswami, Rajib Dey, Debarun Patra and Sourav Dey for helping with some high-quality pictures and information about some species without which this work would have been 
incomplete. We would express our deepest gratefulness to Purnendu Roy, Kalesh Sadasivan, Kalyan Mukherjee, Rajib Dey, Aurnavo Bruno, and Sourav Dey for their assistance in some identification. We would like to thank Dr. Sanjukta Mondal (Parui), Associate Professor, HOD, Coordinator NAAC-UGC, WBES, Post Graduate Department of Zoology, Lady Brabourne College, Kolkata-700017, West Bengal, India. We would like to express our special thanks to Subhadeep Chowdhury, Debarun Patra, and Soumyajit Roy, who helped to survey various remote places in the study area at different times. The authors would akin to thank the all person who has assisted us during our survey, especially the local people of respective areas for their consistent help. District maps are courtesy of the respective District administration and Police administration websites.

\section{References Références Referencias}

1. P. G. May, Flower selection and the dynamics of lipid reserves in two nectarivorous butterflies, Ecology. 73:2181-2191, 1992.

2. J. D. Majer, The conservation and study of invertebrates in remnants of native vegetation. In $\mathrm{D}$. A. Saunders, G. W. Arnold, A. A. Burbridge, and A. J. M. Hopkins (eds). Nature Conservation: The Role of Remnants of Native Vegetation. Surrey Beatty and Sons, Sydney. 333- 33, 1987.

3. S. Naeem, L. J. Thompson, S. P. Lawler, J. H. Lawron and R. M. Woodfin, Declining biodiversity can alter the performance of ecosystem, Nature. 368:734-736, 1994.

4. A. D. Tiple, Butterflies of Vidarbha region, Maharashtra State, central India, Journal of Threatened Taxa. 3(1):1469-1477, 2011.

5. J. A. Thomas, D. J. Simcox, J. C. Wardlaw, W. G. Elmes, M. E. Hochberg and R. T. Clark, Effects of latitude, altitude and climate on the habitat and conservation of the endangered butterfly Maculinea arion and its Myrmica ant host, Journal of Insect Conservation. 2:39-46, 1998.

6. J. A. Fordyce and C. C. Nice, Variation in butterfly egg adhesion: Adaptation to level host plant senescence characteristics? Ecology Letters. 6:2327, 2003.

7. S. J. Biswas, D. Patra, S. Roy, S. K. Giri, S. Paul and A. Hossain, Butterfly diversity throughout Midnapore urban area in West Bengal, India. 11(14): 1481614826, 2019.

8. R. B. Blair and A. E. Launer, Butterfly diversity and human land use: Species assemblages along an urban gradient, Biological Conservation. 80:113125, 1997.

9. P. J. Clark, J. M. Reed and F. S. Chew, Effect of urbanization on butterfly species richness, guild structure and rarity, Urban Ecosystem. 10:321-337, 2007.

10. A. Pocewicz, P. Morgan and S. D. Eigenbrode, Local and landscape effects on butterfly density in northern Idaho grasslands and forests, J. Insect Conserv. 13:593-601, 2009.

11. G. G. Malagrino, M. M. Lagunas and A. O. Rubio, Environmental impact reduction through ecological planning at Bahia Magdalena, Mexico. J. Environ. Biol. 29:79-82, 2008.

12. J. Wood-Manson and L. De-nicevile, List of the Lepidopteran insect's collection in Cachar by Mr. J. Wood -Manson, Journal of the Asiatic Society of Bengal. (42):343-399, 1887.

13. K. Kunte, A. Joglekar, G. Utkarsh and $P$. Padmanabhan, Patterns of butterfly, bird and tree diversity in the Western Ghats, Current Science, 77(4): 577- 586, 1999.

14. P. R. Arun, Butterflies of Siruvani Forests of Western Ghats, with Notes on their seasonality, Zoos Print J., 18(2): 1003-1006, 2003.

15. I. Kehimkar, The Book of Indian Butterflies. Bombay Natural History Society, Mumbai, pp. 1-497, 2008.

16. R.K. Varshney and P. Smetacek (eds.), A Synoptic Catalogue of the Butterflies of India, Indinov Publishing, New Delhi. 261pp, 2015.

17. H. S. Fergusson, A list of butterflies of Travancore, Bombay Natural History Society, Bombay. pp 464, 1891.

18. H. Gaonkar, Butterflies of the Western Ghats, India, including Sri Lanka: Biodiversity assessment of a threatened mountain system, Centre for Ecological Sciences, Indian Institute of Science, Bangalore and the Natural History Museum, London. pp 18.,1996.

19. T. B.Larsen, The butterflies of Nilgiri mountains of southern India (Lepidoptera: Rhopalocera), Journal of Bombay Natural History Society. 85:30-43, 1989.

20. G. M. A. Mathew and C. M. Brijesh, Butterflies of Keral: Biodiversity and Ecology: Concepts and Facts (Eds.: M Sivadasan and K.V. Mohanan), University of Calicut, Calicut. India. 45-49, 2000.

21. V. V. Sudheendrakumar, C. F. Binoy, P. V. Suresh and $G$. Mathew, Habitat associations of butterflies in the Parabikulam Wildlife Sanctuary, Kerala, India, Journal of Bombay Natural History Society. 97:193201, 2000.

22. A. B. Roy, U. Ghosh and K. Kunte, Sighting of Elymnias panther (Lepidoptera: Nymphalidae: Satyrinae) in West Bengal, eastern India, Journal of Threatened Taxa. 2:670-671, 2010.

23. J. Dasgupta, Paschimbanger prajapati, Ananda publishing private limited, Kolkata. pp 204, 2010.

24. R. P.Das, Diversity, Distribution And Bio-Ecology Of Butterfly Communities Of West Bengal, Ph.D. Thesis, University in Calcutta. 2014

25. L.D. Nicéville, List of Butterflies of Calcutta and its neighborhood with notes on habits and food plants, 1 
Journal of the Asiatic Society of Bengal. 54(2):39-54, 1885.

26. D. F.Sanders, A list of and notes on the Butterflies of Calcutta, Journal of the Bengal Natural History Society. 19:29-41, 1944.

27. S. Chowdhury and D. Chowdhury, On the Butterfly Fauna of Chintamoni Kar Bird Sanctuary, West Bengal, Bionotes. 8(1):20, 2006.

28. S. Chowdhury and R. Soren, Butterfly (Lepidoptera: Rhopalocera) Fauna of East Calcutta Wetlands, West Bengal, India, Check List. 7(6):700-703, 2011.

29. S. Chowdhury and R. P. Das, Diversity of Butterflies in the Indian Botanic Garden, Howrah, West Bengal, Bionotes. 9(4):131-132, 2007.

30. S. Dwari, A. K. Mondal and S Chowdhury, Diversity of butterflies (Lepidoptera: Rhopalocera) of Howrah district, West Bengal, India, JEZS. 5(6): 815-828, 2017.

31. K. Mukherjee and A. Mondal, Butterfly diversity in heterogeneous habitat of Bankura, West Bengal, India, Journal of Threatened Taxa.12(8): 1580415816, 2020.

32. K. Hajra, P. Mandal, S. Jana, S. Jana and A. Sahoo, Diversity of Butterfly in Contai and its adjoining areas Purba Medinipur, West Bengal, India, Int.J.Curr.Res.Aca.Rev.2015; 3(6):246-258, 2015.

33. A. Payra, R. K. Mishra and K. Mondal, Butterflies (Lepidoptera - Rhopalocera) of Coastal Areas of Purba Medinipur District, Southern West Bengal, India, Tap Chi Sinh Hoc. 39(3): 276-290, 2017.

34. P. R. Pahari, N. P. Mishra, A. Sahoo and T. Bhattacharya, A study on the butterfly diversity of Haldia industrial belt and adjacent rural area in Purba Medinipur district, West Bengal, India, WSN. 97: 207-224, 2018.

35. Z. A. Mirza and A. Mondal, A new genus with two species of the family Nemesiidae (Araneae: Mygalomorphae) from India, Acta Arachnologica. 67(1): 43-48, 2018.

36. E. Pollard, A method for assessing changes in the abundance of butterflies, Biological Conservation. 12:115-153, 1977.

37. E. Pollard and T. J.Yates, Monitoring Butterflies for Ecology and Conservation. London: Chapman and Hall. pp 274, 1993.

38. K. Kunte, Seasonal patterns in butterfly abundance and species diversity in four tropical habitats in the northern Western Ghats, J Biosci. 22:593-603, 1997.

39. I. Kehimkar, Butterflies of India. Bombay Natural History Society. Mumbai. pp 505, 2016.

40. M. Bhakare and H. Ogale, A Guide to the Butterflies of Western Ghats (India). Maharasthra. Pp 496, 2018.

41. W. H. Evans, The Identification of Indian Butterflies. Bombay: Bombay Natural History Society. pp 464, 1932.
42. G. Talbot, Fauna of British-India including Ceylon and Burma. Butterflies, Vol I and II. Today and Tomorrow's Printers and Publishers, New Delhi, India. 1939-1947.

43. M. A.Wynter-Blyth, Butterflies of the Indian Region. Bombay Natural History Society, Bombay. 1957.

44. M. Haribal, The butterflies of Sikkim Himalaya and their Natural History, Sikkim, Sikkim Natural Conservation Foundation. pp 217, 1992.

45. P. Smetacek, A Naturalist's Guide to the Butterflies of India. John Beaufoy Publishing Ltd. Malaysia. 2017.

46. Ø. Hammer, D. A. T. Harper, P. D. Ryan. PAST: Paleontological Statistics Software Package for Education and Data Analysis. Palaeontologia Electronica. 4(1):9, 2001.

47. C. E. Shannon and W, Wiener,The mathematical theory of communication. Urbana, University of Illinois Press 177, 1949,.

48. R. Margalef, Temporal succession and spatial heterogeneity in phytoplankton. In: Perspectives in Marine biology, Buzzati-Traverso (ed.), Univ. Calif. Press, Berkeley. 323-347, 1958.

49. E. C. Pielou. The measurement of diversity in different types of biological collections. J. Theoret. Biol. 13:131-144, 1966.

50. J. C. Davis, Statistics and Data Analysis in Geology. John Wiley \& Sons. 1986.

51. D. A. T. Harper Numerical Palaeobiology. John Wiley \& Sons. 1999.

52. S. Samanta, D. Das and S Mandal, Butterfly fauna of Baghmundi, Purulia, West Bengal, India: A Preliminary Checklist, Journal of Threatened Taxa.9(5): 10198-10207, 2017.

53. I. J. Gupta, Insecta: Lepiodeptera: Lycaenidae, State Fauna Series 3: Fauna of West Bengal, Zoological Survey of India, Calcutta. 7:429-489, 1997.

54. G, Sharma and P. C. Joshi, Diversity of butterflies (Lepidoptera: Insecta) from Dholbaha dam (Distt. Hoshiarpur) in Punjab Shivalik, India. Biological Forum. 1:11-14, 2009. 
Table 1: List of butterflies recorded from The District Jhargram, Paschim and Purba Medinipur districts, West Bengal, India

\begin{tabular}{|c|c|c|c|c|c|c|c|}
\hline Family & $\begin{array}{r}\text { SI } \\
\text { No. }\end{array}$ & Common name & Scientific name & Jhargram & $\begin{array}{l}\text { Paschim } \\
\text { Medinipur }\end{array}$ & $\begin{array}{c}\text { Purba } \\
\text { Medinipur }\end{array}$ & Status \\
\hline \multirow[t]{11}{*}{ Papilionidae } & 1 & Common Mormon & Papilio polytes (Linnaeus, 1758) & + & + & + & VC \\
\hline & 2 & Blue Mormon & $\begin{array}{l}\text { Papilio polymnestor (Cramer, } \\
\text { 1775) }\end{array}$ & + & + & + & C \\
\hline & 3 & Lime Butterfly & $\begin{array}{l}\text { Papilio demoleus (Linnaeus, } \\
\text { 1758) }\end{array}$ & + & + & + & VC \\
\hline & 4 & Common Mime & Papilio clytia (Linnaeus, 1758) & + & + & + & VC \\
\hline & 5 & $\begin{array}{l}\text { Common Banded } \\
\text { Peacock }\end{array}$ & Papilio crino (Fabricius, 1793) & + & + & + & C \\
\hline & 6 & Common Rose & $\begin{array}{l}\text { Pachliopta aristolochiae } \\
\text { (Fabricius, 1775) }\end{array}$ & + & + & + & VC \\
\hline & 7 & Crimson Rose & $\begin{array}{l}\text { Pachliopta hector (Linnaeus, } \\
\text { 1758) }\end{array}$ & + & + & + & LC \\
\hline & 8 & Common Jay & $\begin{array}{l}\text { Graphium doson (C and R. } \\
\text { Felder, 1864) }\end{array}$ & + & + & + & VC \\
\hline & 9 & Tailed Jay & $\begin{array}{l}\text { Graphium agamemnon } \\
\text { (Linnaeus, 1758) }\end{array}$ & + & + & + & VC \\
\hline & 10 & Spot Swordtail & Graphium nomius (Esper, 1793) & + & + & & LC \\
\hline & 11 & Fivebar Swordtail & $\begin{array}{l}\text { Graphium antiphates (Cramer, } \\
\text { 1775) }\end{array}$ & + & & & $\mathrm{R}$ \\
\hline \multirow[t]{17}{*}{ Pieridae } & 12 & Psyche & Leptosia nina (Fabricius, 1793) & + & + & + & VC \\
\hline & 13 & Common Gull & $\begin{array}{l}\text { Cepora nerissa (Fabricius, } \\
1775)\end{array}$ & + & + & + & VC \\
\hline & 14 & Yellow Orange Tip & Ixias pyrene (Linnaeus, 1764) & + & + & + & $\mathrm{C}$ \\
\hline & 15 & White Orange Tip & Ixias marianne (Cramer, 1779) & + & + & & $\mathrm{LC}$ \\
\hline & 16 & Common Jezebel & Delias eucharis (Drury, 1773) & + & + & + & VC \\
\hline & 17 & Striped Albatross & $\begin{array}{l}\text { Appias libythea (Fabricius, } \\
1775 \text { ) }\end{array}$ & + & + & + & VC \\
\hline & 18 & Indian cabbage White & Pieris canidia (Linnaeus, 1768) & + & + & + & $\mathrm{C}$ \\
\hline & 19 & Common Wanderer & Pareronia valeria (Cramer, 1776) & + & + & + & VC \\
\hline & 20 & Pioneer & $\begin{array}{l}\text { Belenois aurota (Fabricius, } \\
\text { 1793) }\end{array}$ & + & + & + & $\mathrm{C}$ \\
\hline & 21 & Small Salmon Arab & Colotis amata (Fabricius, 1775) & & & + & LC \\
\hline & 22 & Common Emigrant & $\begin{array}{l}\text { Catopsilia Pomona (Fabricius, } \\
1775)\end{array}$ & + & + & + & VC \\
\hline & 23 & Mottled Emigrant & $\begin{array}{l}\text { Catopsilia pyranthe(Linnaeus, } \\
\text { 1758) }\end{array}$ & + & + & + & VC \\
\hline & 24 & Common Grass Yellow & $\begin{array}{l}\text { Eurema hecabe (Linnaeus, } \\
\text { 1758) }\end{array}$ & + & + & + & VC \\
\hline & 25 & $\begin{array}{l}\text { Three Spot Grass } \\
\text { Yellow }\end{array}$ & $\begin{array}{l}\text { Eurema blanda (Boisduval, } \\
\text { 1836) }\end{array}$ & + & + & + & LC \\
\hline & 26 & One Spot Grass Yellow & $\begin{array}{l}\text { Eurema andersoni (Moore, } \\
1886 \text { ) }\end{array}$ & + & + & & $\mathrm{R}$ \\
\hline & 27 & Spotless Grass Yellow & Eurema laeta (Boisduval, 1836) & + & & & VR \\
\hline & 28 & Small Grass Yellow & Eurema brigitta (Stoll, 1780) & + & + & + & $\mathrm{C}$ \\
\hline \multirow[t]{7}{*}{ Lycaenidae } & 29 & Indian Sunbeam & Curetis thetis (Hubner, 1819) & + & + & + & $\mathrm{C}$ \\
\hline & 30 & Angled Sunbeam & Curetis acuta (Moore, 1877) & + & & & VR \\
\hline & 31 & Falcate Oakblue & $\begin{array}{l}\text { Mahathala ameria (Hewitson, } \\
\text { 1862) }\end{array}$ & + & + & + & VC \\
\hline & 32 & Indian Oakblue & $\begin{array}{l}\text { Arthopala atrax (Hewitson, } \\
\text { 1862) }\end{array}$ & + & + & & $\mathrm{C}$ \\
\hline & 33 & Large Oakblue & $\begin{array}{l}\text { Arthopala amantes (Hewitson, } \\
\text { 1862) }\end{array}$ & + & + & & LC \\
\hline & 34 & Silverstreak Blue & Iraota timoleon (Stoll, 1790) & + & + & + & C \\
\hline & 35 & Common Guava Blue & Virachola isocrates (Fabricius, & + & + & + & C \\
\hline
\end{tabular}




\begin{tabular}{|c|c|c|c|c|c|c|c|}
\hline & & & 1793) & & & & \\
\hline & 36 & Purple Leaf Blue & $\begin{array}{l}\text { Amblypodia anita (Hewitson, } \\
\text { 1862) }\end{array}$ & + & + & & C \\
\hline & 37 & Redspot & & & & + & VR \\
\hline & 38 & Peacock Royal & Tajuria cippus (Fabricius, 1798) & + & + & + & $\mathrm{C}$ \\
\hline & 39 & Broadtail Royal & Creon cleobis (Godart, 1824) & + & + & + & $\mathrm{C}$ \\
\hline & 40 & Fluffy Tit & Zeltus amasa (Hewitson, 1865) & + & & & VR \\
\hline & 41 & Yamfly & Loxura atymnus (Cramer, 1782) & + & + & + & $\mathrm{C}$ \\
\hline & 42 & Monkey Puzzle & Rathinda amor (Fabricius, 1775) & + & + & + & VC \\
\hline & 43 & Indian Red Flash & Rapala iarbus (Fabricius, 1787) & + & + & + & LC \\
\hline & 44 & Slate Flash & Rapala manea (Hewitson, 1863) & + & + & + & VC \\
\hline & 45 & Indigo Flash & Rapala varuna (Hewitson, 1863) & + & & & $\mathrm{R}$ \\
\hline & 46 & Common Silverline & $\begin{array}{l}\text { Spindasis vulcanus (Fabricius, } \\
1775 \text { ) }\end{array}$ & + & + & + & VC \\
\hline & 47 & Common Shot Silverline & Spindasis ictis (Hewitson, 1865) & + & + & + & C \\
\hline & 48 & Long- banded Silverline & $\begin{array}{l}\text { Spindasis lohita (Horsfield, } \\
\text { 1829) }\end{array}$ & + & + & + & LC \\
\hline & 49 & Common Pierrot & $\begin{array}{l}\text { Castalius rosimon (Fabricius, } \\
1775 \text { ) }\end{array}$ & + & + & + & VC \\
\hline & 50 & & Tarucus sp. (Moore, 1881) & + & + & + & VC \\
\hline & 51 & Angled Pierrot & Calida decidia (Hewitson, 1876) & + & & & VR \\
\hline & 52 & Zebra Blue & $\begin{array}{l}\text { Leptotes plinius (Fabricius, } \\
\text { 1793) }\end{array}$ & + & + & + & $\mathrm{VC}$ \\
\hline & 53 & Apefly & $\begin{array}{l}\text { Spalgis epeus (Westwood, } \\
\text { 1851) }\end{array}$ & + & + & + & $\mathrm{C}$ \\
\hline & 54 & Common Lineblue & Prosotas nora (Felder, 1860) & + & + & + & C \\
\hline & 55 & Tailless Lineblue & $\begin{array}{l}\text { Prosotas dubiosa (Semper, } \\
\text { 1879) }\end{array}$ & + & + & + & VC \\
\hline & 56 & Common Cerulean & Jamides celeno (Cramer, 1775) & + & + & + & VC \\
\hline & 57 & Dark Cerulean & Jamides bochus (Stoll, 1782) & + & + & + & C \\
\hline & 58 & Common Ciliate Blue & Anthene emolus (Godart, 1823) & + & + & + & $\mathrm{C}$ \\
\hline & 59 & Pointed Ciliate Blue & $\begin{array}{l}\text { Anthene lycaenina (C. Felder, } \\
\text { 1868) }\end{array}$ & + & + & + & VC \\
\hline & 60 & Forget Me Not & $\begin{array}{l}\text { Catochrysops strabo (Fabricius, } \\
\text { 1793) }\end{array}$ & + & + & + & VC \\
\hline & 61 & Pea Blue & $\begin{array}{l}\text { Lampides boeticus (Linnaeus, } \\
1767 \text { ) }\end{array}$ & + & + & + & VC \\
\hline & 62 & Dark Grass Blue & $\begin{array}{l}\text { Zizeeria karsandra (Moore, } \\
\text { 1865) }\end{array}$ & + & + & + & $\mathrm{C}$ \\
\hline & 63 & Pale Grass Blue & $\begin{array}{l}\text { Pseudozizeeria maha (Kollar, } \\
\text { 1848) }\end{array}$ & + & + & + & VC \\
\hline & 64 & Lesser Grass Blue & Zizina otis (Fabricius, 1787) & + & + & + & $\mathrm{C}$ \\
\hline & 65 & Tiny Grass Blue & Zizula hylax (Fabricius, 1775) & + & + & + & VC \\
\hline & 66 & Grass Jewel & $\begin{array}{l}\text { Chilades trochylus (Freyer, } \\
\text { 1845) }\end{array}$ & + & + & & LC \\
\hline & 67 & Common Hedge Blue & $\begin{array}{l}\text { Acytolepis puspa (Horsfield, } \\
\text { 1828) }\end{array}$ & + & + & & $\mathrm{R}$ \\
\hline & 68 & Malayan & $\begin{array}{l}\text { Megisba malaya (Horsfield, } \\
1828)\end{array}$ & + & & & $\mathrm{R}$ \\
\hline & 69 & Quaker & $\begin{array}{l}\text { Neopithecops zalmora (Butler, } \\
\text { 1870) }\end{array}$ & + & + & + & VC \\
\hline & 70 & Gram Blue & $\begin{array}{l}\text { Euchrysops cnejus (Fabricius, } \\
1798 \text { ) }\end{array}$ & + & + & + & VC \\
\hline & 71 & Plains Cupid & $\begin{array}{l}\text { Chilades pandava (Horsfield, } \\
\text { 1829) }\end{array}$ & + & + & + & VC \\
\hline & 72 & Lime Blue & Chilades lajus (Cramer, 1782) & + & + & + & VC \\
\hline Riodinidae & 73 & $\begin{array}{l}\text { Double-banded Judy } \\
\text { or Twospot Plum Judy }\end{array}$ & $\begin{array}{l}\text { Abisara bifasciata (Moore, } \\
1877 \text { ) }\end{array}$ & + & + & + & C \\
\hline $\begin{array}{c}\text { Nymphalida } \\
\text { e }\end{array}$ & 74 & Blue Tiger & $\begin{array}{l}\text { Tirumala limniace (Cramer, } \\
\text { 1775) }\end{array}$ & + & + & + & VC \\
\hline & 75 & Plain Tiger & Danaus chrysippus (Linnaeus, & + & + & + & $\mathrm{VC}$ \\
\hline
\end{tabular}




\begin{tabular}{|c|c|c|c|c|c|c|}
\hline & & 1758) & & & & \\
\hline 76 & Striped Tiger & $\begin{array}{l}\text { Danaus genutia } \\
\text { (Cramer, 1779) }\end{array}$ & + & + & + & VC \\
\hline 77 & White Tiger & $\begin{array}{l}\text { Danaus melanippus (Cramer, } \\
1777 \text { ) }\end{array}$ & & & + & LC \\
\hline 78 & Common Crow & Euploea core (Cramer, 1780) & + & + & + & VC \\
\hline 79 & Brown King Crow & Euploea klugii (Moore,1858) & + & + & + & $\mathrm{C}$ \\
\hline 80 & Common Nawab & Polyura athamas (Drury,1773) & + & & & VR \\
\hline 81 & Black Rajah & $\begin{array}{l}\text { Charaxes solon (Fabricius, } \\
1793 \text { ) }\end{array}$ & + & + & + & LC \\
\hline 82 & Tawny Rajah & $\begin{array}{l}\text { Charaxes bernardus } \\
\text { (Fabricius, 1793) }\end{array}$ & + & & & $\mathrm{R}$ \\
\hline 83 & $\begin{array}{l}\text { Common Evening } \\
\text { Brown }\end{array}$ & Melanitis leda (Linnaeus, 1758) & + & + & + & VC \\
\hline 84 & Bamboo Treebrown & $\begin{array}{l}\text { Lethe europa } \\
\text { (Fabricious, 1787) }\end{array}$ & + & + & + & C \\
\hline 85 & Common Palmfly & $\begin{array}{l}\text { Elymnias hypermnestra } \\
\text { (Linnaeus, 1763) }\end{array}$ & + & + & + & VC \\
\hline 86 & Common Bushbrown & $\begin{array}{l}\text { Mycalesis perseus (Fabricius, } \\
1775 \text { ) }\end{array}$ & + & + & + & $\mathrm{VC}$ \\
\hline 87 & Dark Brand Bushbrown & $\begin{array}{l}\text { Mycalesis mineus (Linnaeus, } \\
1758)\end{array}$ & + & + & + & C \\
\hline 88 & Common Five Ring & $\begin{array}{l}\text { Ypthima baldus (Fabricius, } \\
1775)\end{array}$ & + & + & + & VC \\
\hline 89 & Common Four Ring & Ypthima huebneri (Kirby, 1871) & + & + & + & VC \\
\hline 90 & Common Duffer & $\begin{array}{l}\text { Discophora sondaica } \\
\text { (Boisduval, 1836) }\end{array}$ & + & + & + & $\mathrm{C}$ \\
\hline 91 & Tawny Coster & Acraea violae (Fabricius, 1775) & + & + & + & VC \\
\hline 92 & Common Leopard & $\begin{array}{l}\text { Phalanta phalantha (Drury, } \\
\text { 1773) }\end{array}$ & + & + & + & VC \\
\hline 93 & Commander & Moduza procris (Cramer, 1777) & + & + & + & $\mathrm{VC}$ \\
\hline 94 & Angled Castor & $\begin{array}{l}\text { Ariadne ariadne(Linnaeus, } \\
1764 \text { ) }\end{array}$ & + & + & + & VC \\
\hline 95 & Common Castor & $\begin{array}{l}\text { Ariadne merione (Cramer, } \\
1777 \text { ) }\end{array}$ & + & + & + & VC \\
\hline 96 & Common Sailer & Neptis hylas (Linnaeus, 1758) & + & + & + & $\mathrm{C}$ \\
\hline 97 & $\begin{array}{l}\text { Chestnut - streaked } \\
\text { Sailer }\end{array}$ & Neptis jumbah (Moore, 1857) & + & + & + & VC \\
\hline 98 & Common Sergeant & Athyma perius (Linnaeus, 1758) & + & + & & LC \\
\hline 99 & Common Lascar & $\begin{array}{l}\text { Pantoporia hordonia (Stoll, } \\
\text { 1790) }\end{array}$ & + & & & VR \\
\hline 100 & Common Barron & $\begin{array}{l}\text { Euthalia aconthea (Hewitson, } \\
\text { 1874) }\end{array}$ & + & + & + & VC \\
\hline 101 & Gaudy Barron & $\begin{array}{l}\text { Euthalia lubentina (Cramer, } \\
\text { 1777) }\end{array}$ & + & + & + & LC \\
\hline 102 & Baronet & $\begin{array}{l}\text { Symphaedra nais (Forster, } \\
1771 \text { ) }\end{array}$ & + & + & & VC \\
\hline 103 & Painted Lady & $\begin{array}{l}\text { Vanessa cardui (Linnaeus, } \\
\text { 1758) }\end{array}$ & + & + & + & C \\
\hline 104 & Blue Pansy & $\begin{array}{l}\text { Junonia orithya (Linnaeus, } \\
\text { 1758) }\end{array}$ & + & + & + & VC \\
\hline 105 & Yellow Pansy & Junonia hierta (Fabricius, 1798) & + & + & + & $\mathrm{C}$ \\
\hline 106 & Chocolate Pansy & Junonia iphtia (Cramer, 1779) & + & + & + & $\mathrm{C}$ \\
\hline 107 & Lemon Pansy & $\begin{array}{l}\text { Junonia lemonias (Linnaeus, } \\
\text { 1758) }\end{array}$ & + & + & + & VC \\
\hline 108 & Grey Pansy & Junonia atlites (Linnaeus, 1763) & + & + & + & VC \\
\hline 109 & Peacock Pansy & $\begin{array}{l}\text { Junonia almana (Linnaeus, } \\
\text { 1758) }\end{array}$ & + & + & + & VC \\
\hline 110 & Great Eggfly & $\begin{array}{l}\text { Hypolimnas bolina (Linnaeus, } \\
\text { 1758) }\end{array}$ & + & + & + & VC \\
\hline 111 & Danaid Eggfly & Hypolimnas misippus(Linnaeus, & + & + & + & $\mathrm{VC}$ \\
\hline
\end{tabular}




\begin{tabular}{|c|c|c|c|c|c|c|}
\hline & & 1764) & & & & \\
\hline 112 & Brown Awl & $\begin{array}{l}\text { Badamia exclamationis } \\
\text { (Fabricius, 1775) }\end{array}$ & + & + & + & $\mathrm{C}$ \\
\hline 113 & Common Banded Awl & $\begin{array}{l}\text { Hasora chromas (Cramer, } \\
1780)\end{array}$ & + & + & + & $\mathrm{C}$ \\
\hline 114 & Common Snow Flat & Tagiades japetus (Stoll, 1782) & + & + & + & VC \\
\hline 115 & Water Snow Flat & $\begin{array}{l}\text { Tagiades litigiosa (Moeschler, } \\
\text { 1878) }\end{array}$ & + & + & + & LC \\
\hline 116 & Tricolour Pied Flat & Coladenia indrani (Moore, 1866) & + & + & & $\mathrm{R}$ \\
\hline 117 & Golden Angle & $\begin{array}{l}\text { Caprona ransonnetii (Felder, } \\
\text { 1868) }\end{array}$ & + & & & $\mathrm{R}$ \\
\hline 118 & Indian Skipper & Spialia galba (Fabricius, 1793) & + & + & + & C \\
\hline 119 & Bush Hopper & $\begin{array}{l}\text { Ampitta dioscorides (Fabricius, } \\
1793 \text { ) }\end{array}$ & + & + & + & VC \\
\hline 120 & Moore's Ace & Halpe porus (Mabille, 1876) & + & + & + & LC \\
\hline 121 & Forest Hopper & $\begin{array}{l}\text { Astictopterus jama (Felder and } \\
\text { Felder, 1860) }\end{array}$ & + & + & + & LC \\
\hline 122 & Chestnut Bob & lambrix salsala (Moore, 1865) & + & + & + & VC \\
\hline 123 & Indian Palm Bob & $\begin{array}{l}\text { Suastus gremius (Fabricius, } \\
\text { 1798) }\end{array}$ & + & + & + & VC \\
\hline 124 & Grass Demon & Udaspes folus (Cramer, 1775) & + & + & + & VC \\
\hline 125 & Tree Flitter & $\begin{array}{l}\text { Hyarotis adrastus (Cramer, } \\
1780)\end{array}$ & + & + & + & VC \\
\hline 126 & $\begin{array}{l}\text { Banana Redeye or } \\
\text { Banana Skipper }\end{array}$ & Erionota torus (Evans, 1941) & + & + & + & $\mathrm{C}$ \\
\hline 127 & Common Red Eye & Matapa aria (Moore, 1865) & + & + & + & VC \\
\hline 128 & Ceylon Swift & Parnara bada (Moore, 1878) & + & + & + & VC \\
\hline 129 & Evan's Swift & Parnara ganga (Evans, 1937) & + & + & + & LC \\
\hline 130 & Rice Swift & Borbo cinnara (Wallace, 1866) & + & + & + & $\mathrm{C}$ \\
\hline 131 & Obscure Branded Swift & Pelopidas agna (Moore, 1865) & + & + & + & VC \\
\hline 132 & Conjoined Swift & $\begin{array}{l}\text { Pelopidas conjuncta (Herrich- } \\
\text { Schaeffer, 1869) }\end{array}$ & + & + & + & LC \\
\hline 133 & Variable Swift & $\begin{array}{l}\text { Pelopidas mathias (Fabricius, } \\
\text { 1798) }\end{array}$ & + & + & + & $\mathrm{LC}$ \\
\hline 134 & Paintbush Swift & Baoris farri (Moore, 1878) & + & + & + & $\mathrm{C}$ \\
\hline 135 & Common Grass Dart & $\begin{array}{l}\text { Taractrocera maevius } \\
\text { (Fabricius, 1793) }\end{array}$ & + & + & + & C \\
\hline 136 & Common Dartlet & Oriens gola (Moore, 1877) & + & + & + & VC \\
\hline 137 & $\begin{array}{l}\text { Common or Pale Palm } \\
\text { Dart }\end{array}$ & Telicota colon (Fabricius, 1775) & + & + & + & C \\
\hline 138 & Dark Palm Dart & $\begin{array}{l}\text { Telicota bambusae (Moore, } \\
\text { 1778) }\end{array}$ & + & + & + & VC \\
\hline 139 & Plain Palm Dart & $\begin{array}{l}\text { Cephrenes acalle (Hopffer, } \\
\text { 1874) }\end{array}$ & + & + & + & $\mathrm{LC}$ \\
\hline
\end{tabular}

[VC-Very Common, C-Common, LC-Less Common, R-Rare, VR-Very Rare]

Table 2: Diversity Indices

(Through PAST software Version 3.02)

\begin{tabular}{|c|c|c|c|}
\hline Diversity Indices & Jhargram & Paschim Medinipur & Purba Medinipur \\
\hline Taxa_S & 136 & 125 & 117 \\
\hline Simpson_1-D & 0.9918 & 0.9915 & 0.9908 \\
\hline Dominance_D & 0.008183 & 0.008523 & 0.009192 \\
\hline Shannon_H & 4.847 & 4.795 & 4.719 \\
\hline Evenness_e^H/S & 0.9368 & 0.9668 & 0.9579 \\
\hline Margalef & 15.02 & 13.83 & 13.03 \\
\hline Fisher_alpha & 23.27 & 21.13 & 19.75 \\
\hline
\end{tabular}

[Based on Diversity, Frequency and Numbers] 


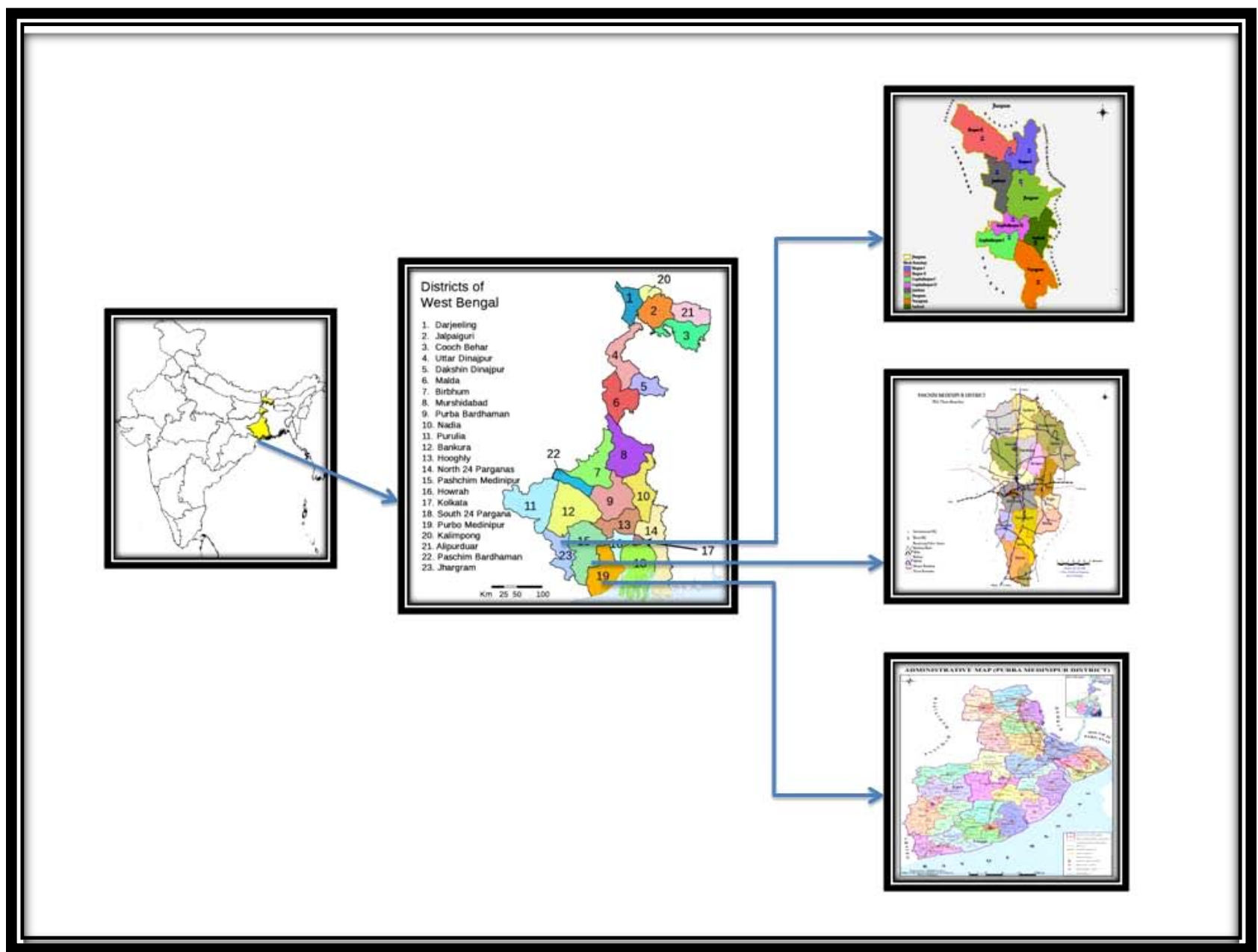

Figure 1: Study Area (A: West Bengal in India, B: West Bengal, C: Jhargram district, D: Paschim Medinipur district, E: Purba Medinipur district 


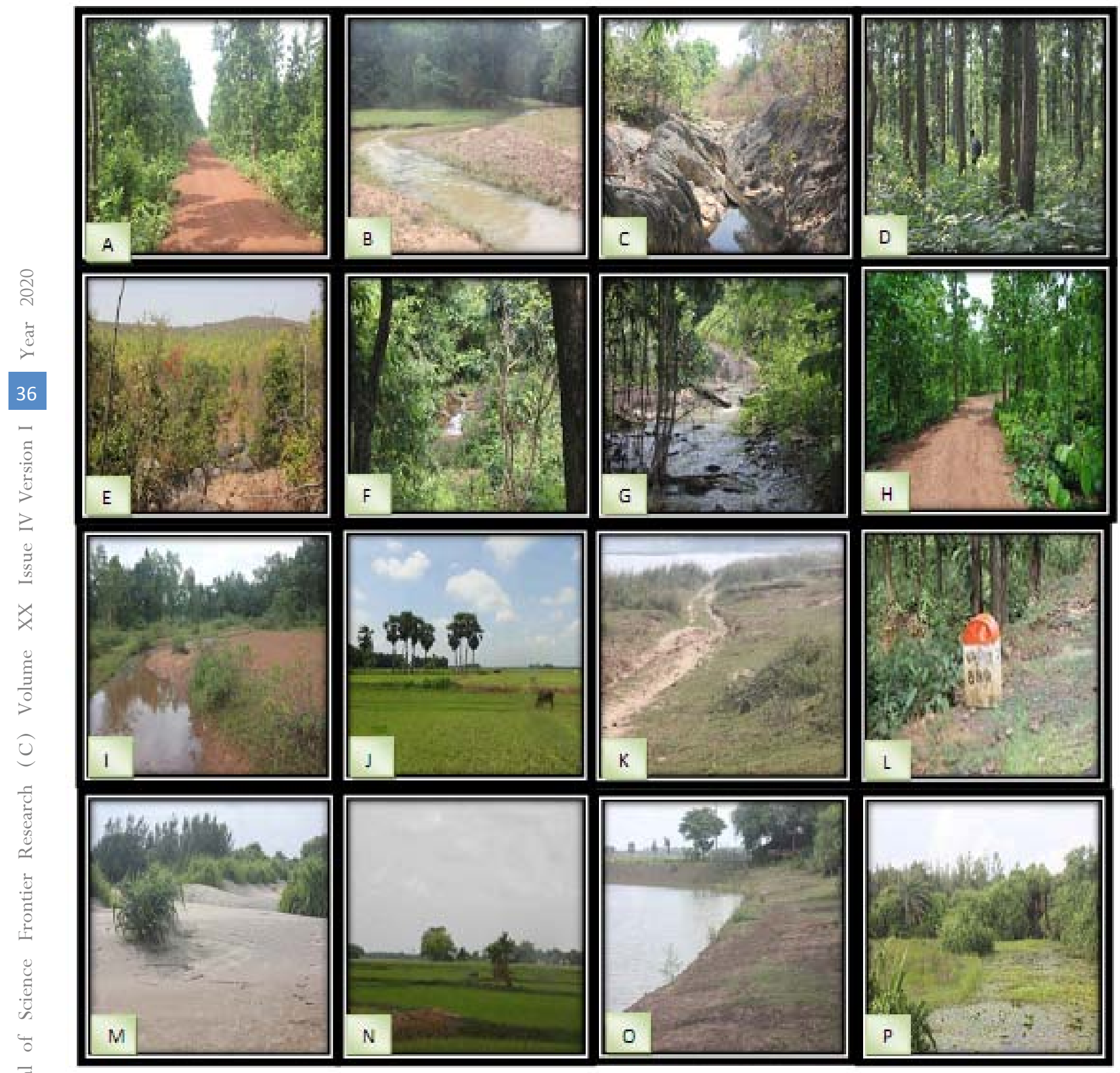

Figure 2: Habitats of Butterflies. A -H) Different habitats of district Jhargram. I -L) Different habitats of district Paschim Medinipur. M-P) Different habitats of district Purba Medinipur 


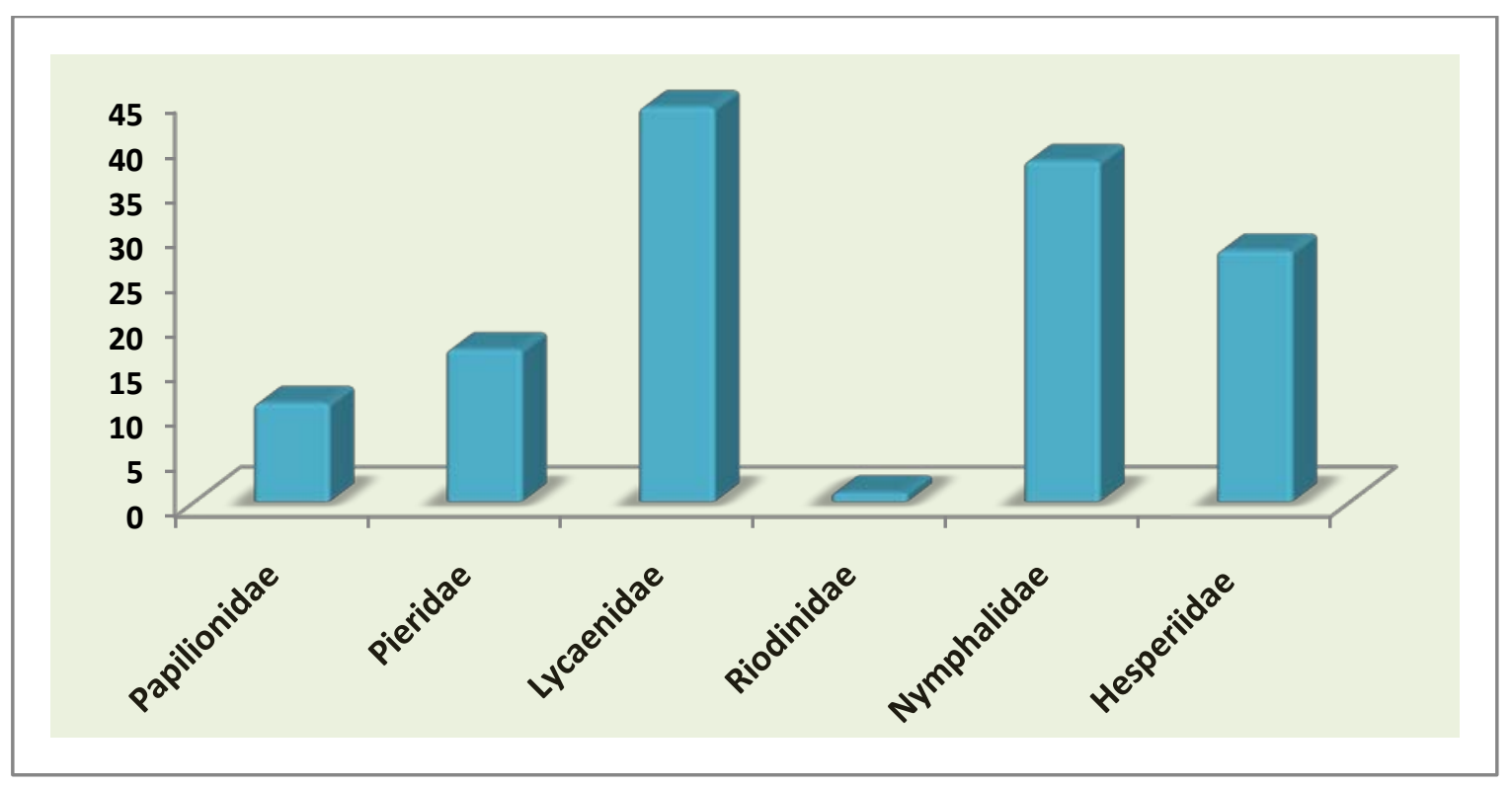

Figure 3: Number wise graphical representation of butterfly species
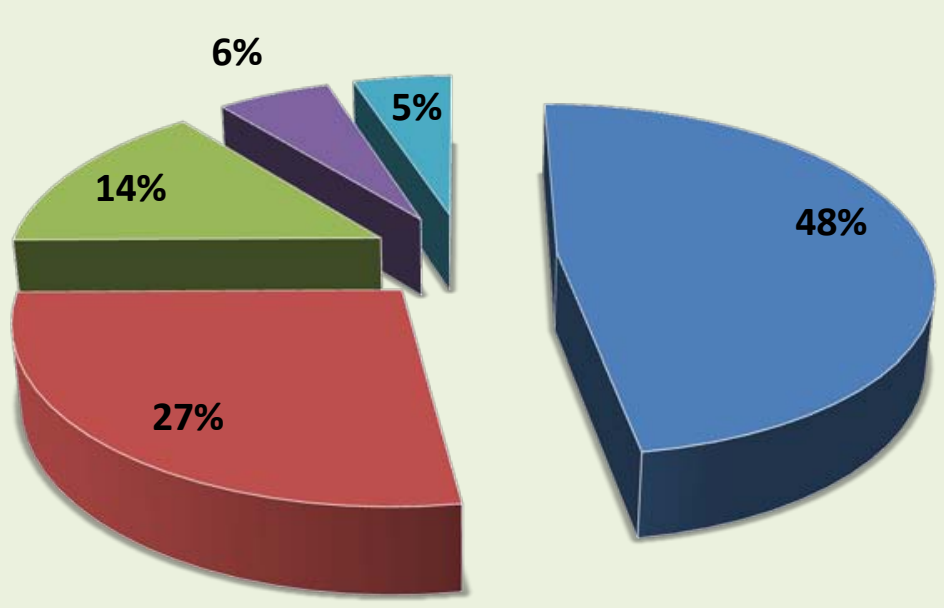

$\square$ Very Common $\square$ Common $\square$ Less Common $\square$ Rare $\square$ Very Rare

Figure 4: Status wise graphical representation of butterfly species 


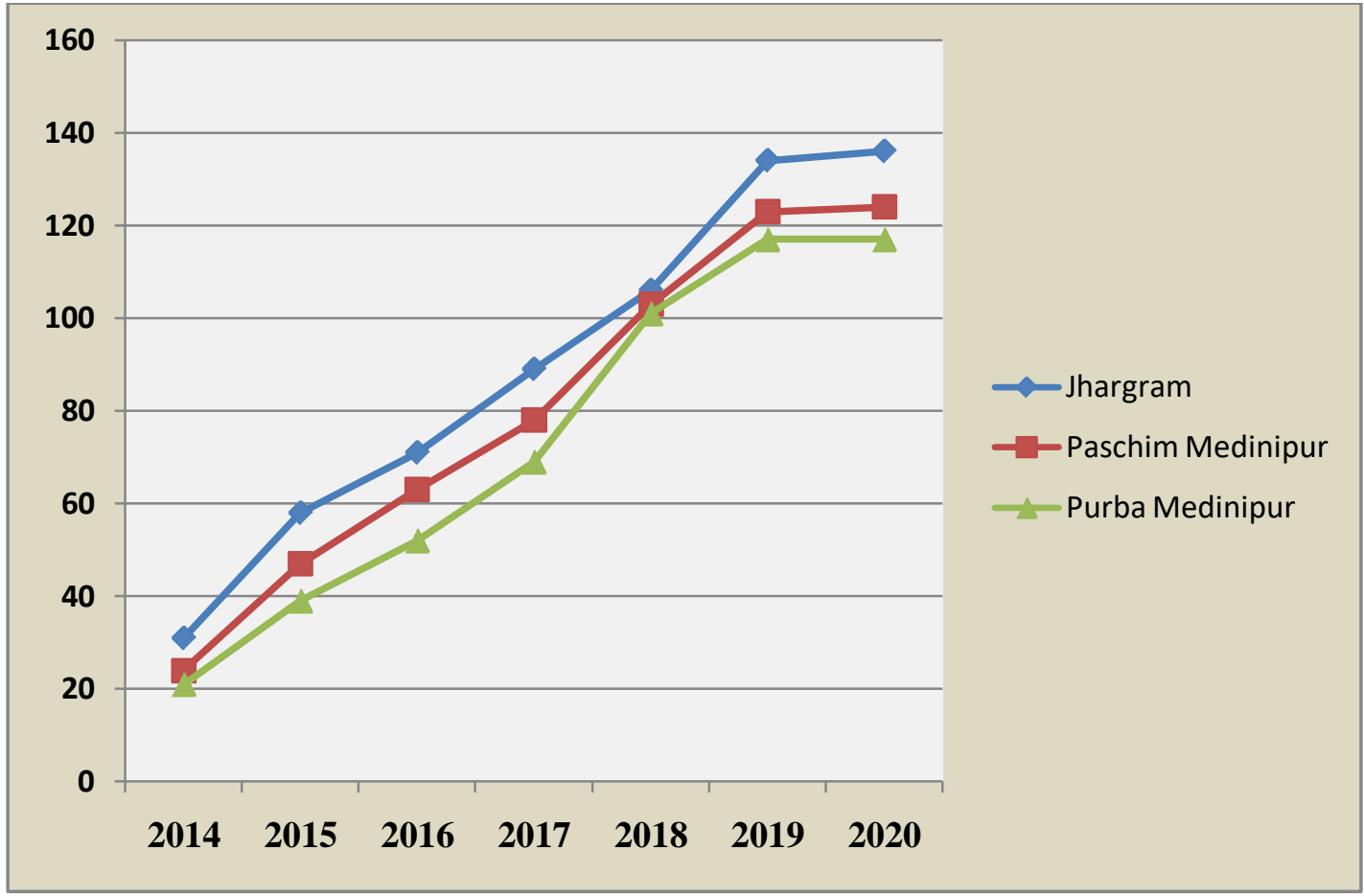

Figure 5: Species Accumulation Curve

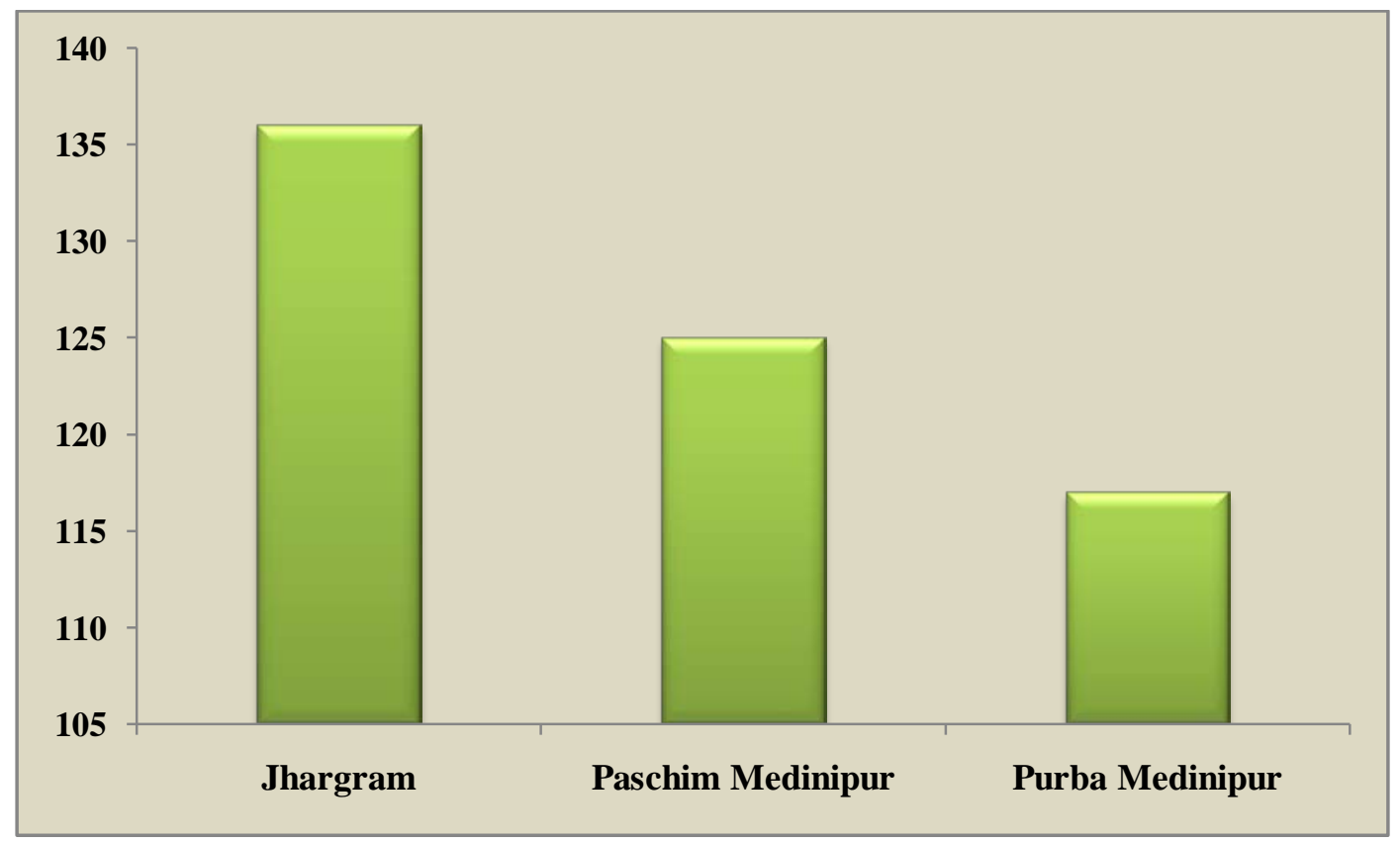

Figure 6: District wise graphical representation of butterfly species 


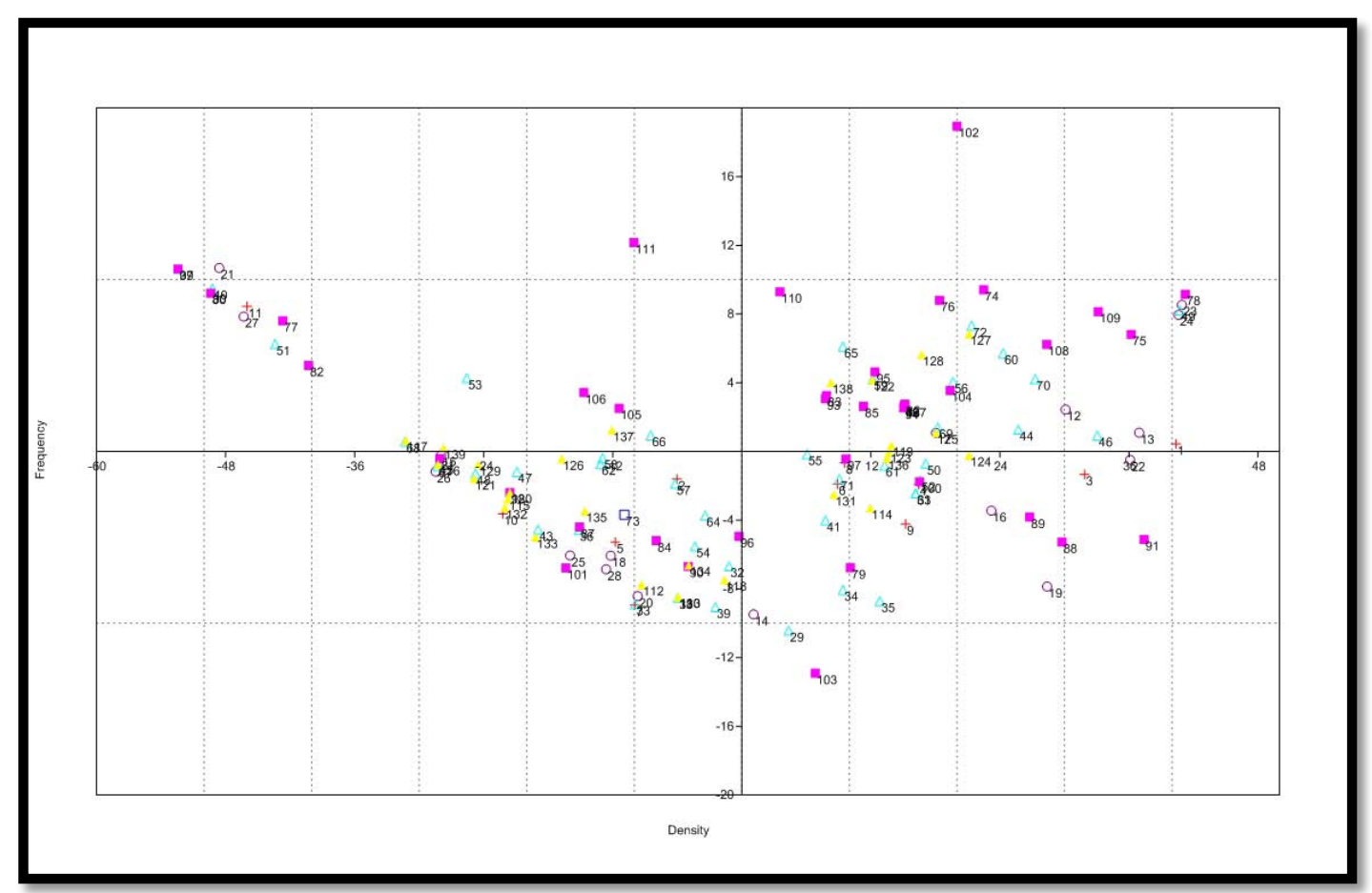

Figure 7: Scatter View of Principal component analysis (PCA)

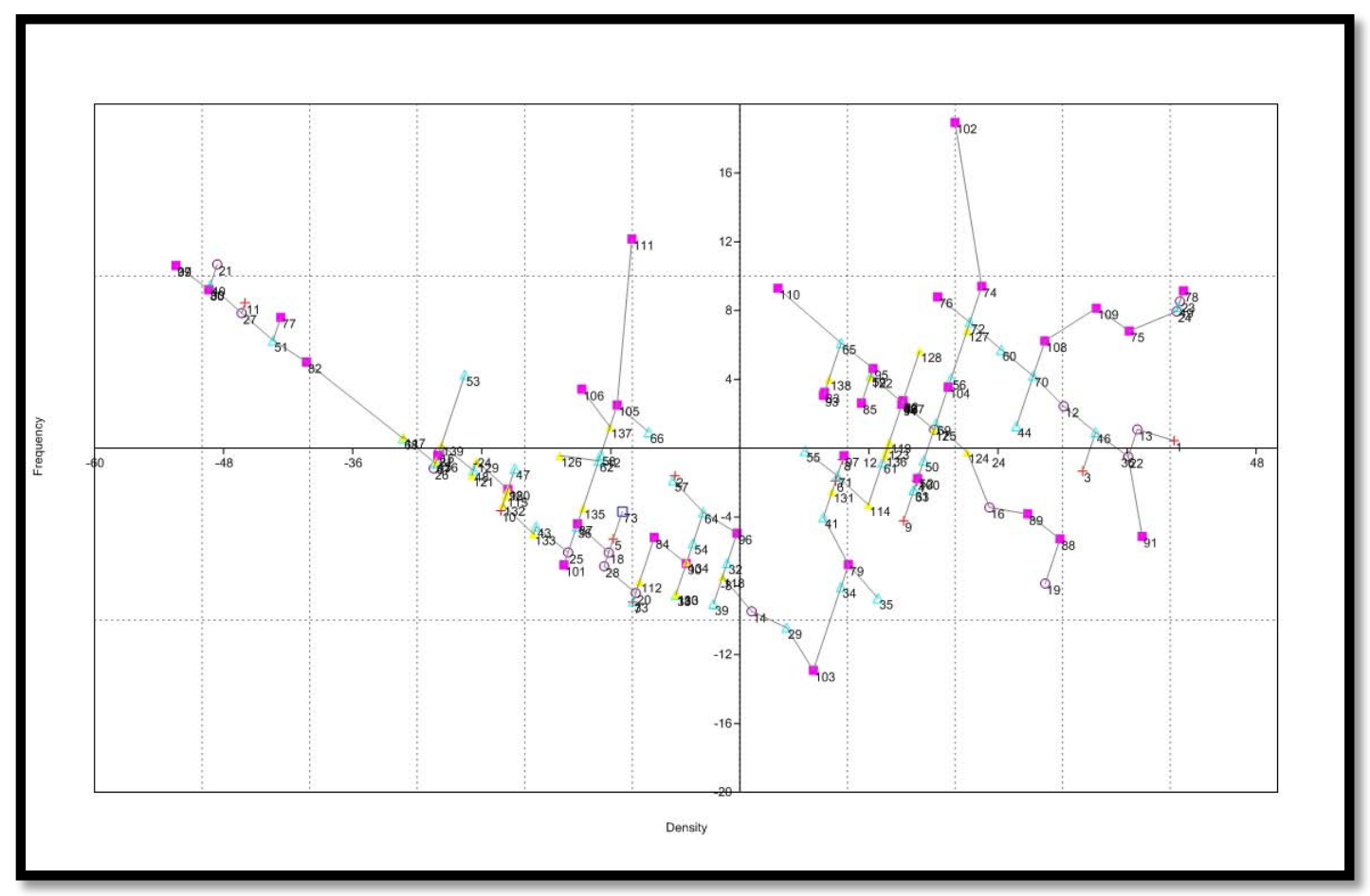

Figure 8: Scatter View of Principal component analysis (PCA) with span 


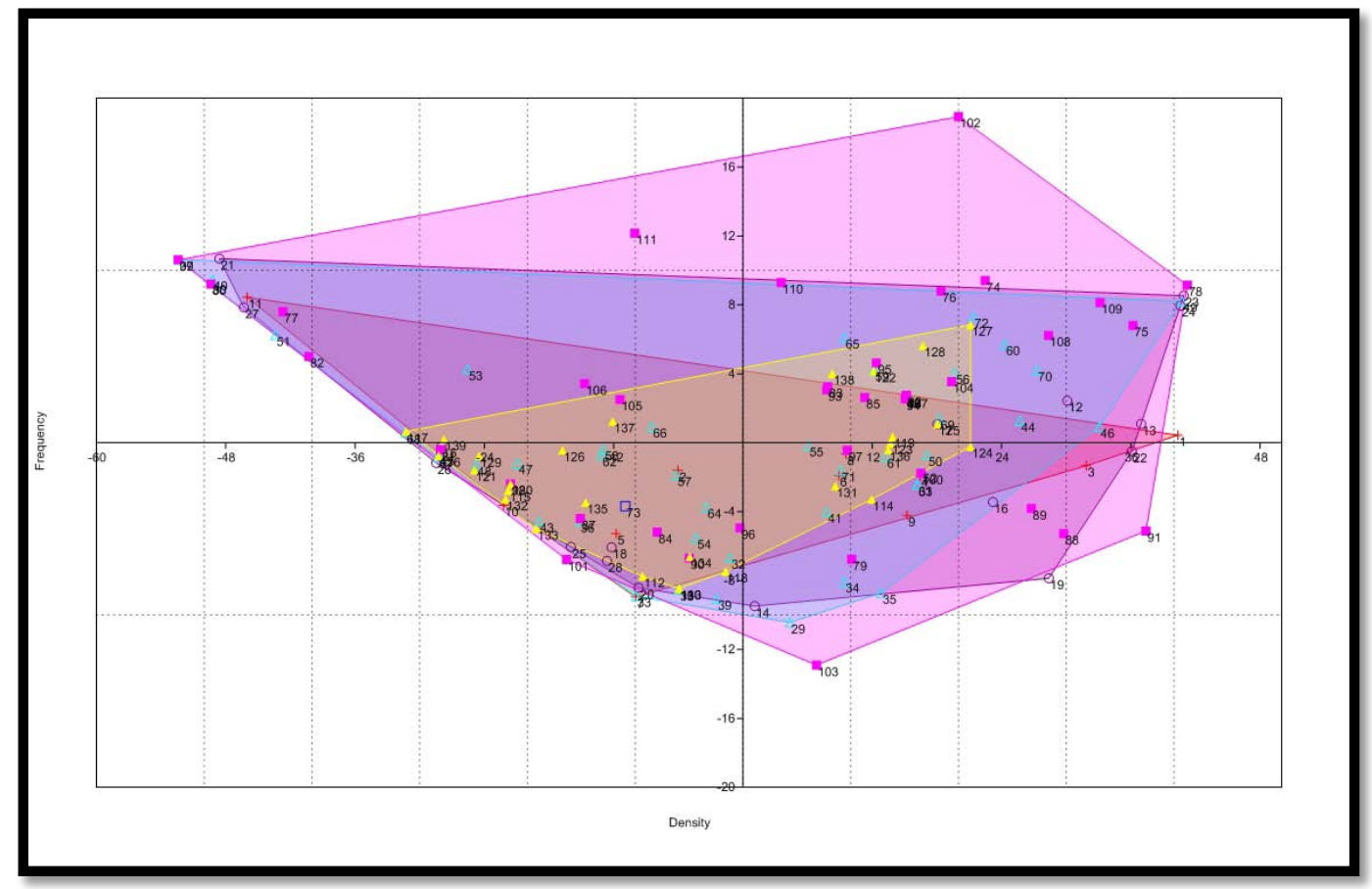

Figure 9: Scatter View of Principal component analysis (PCA) showing extension region

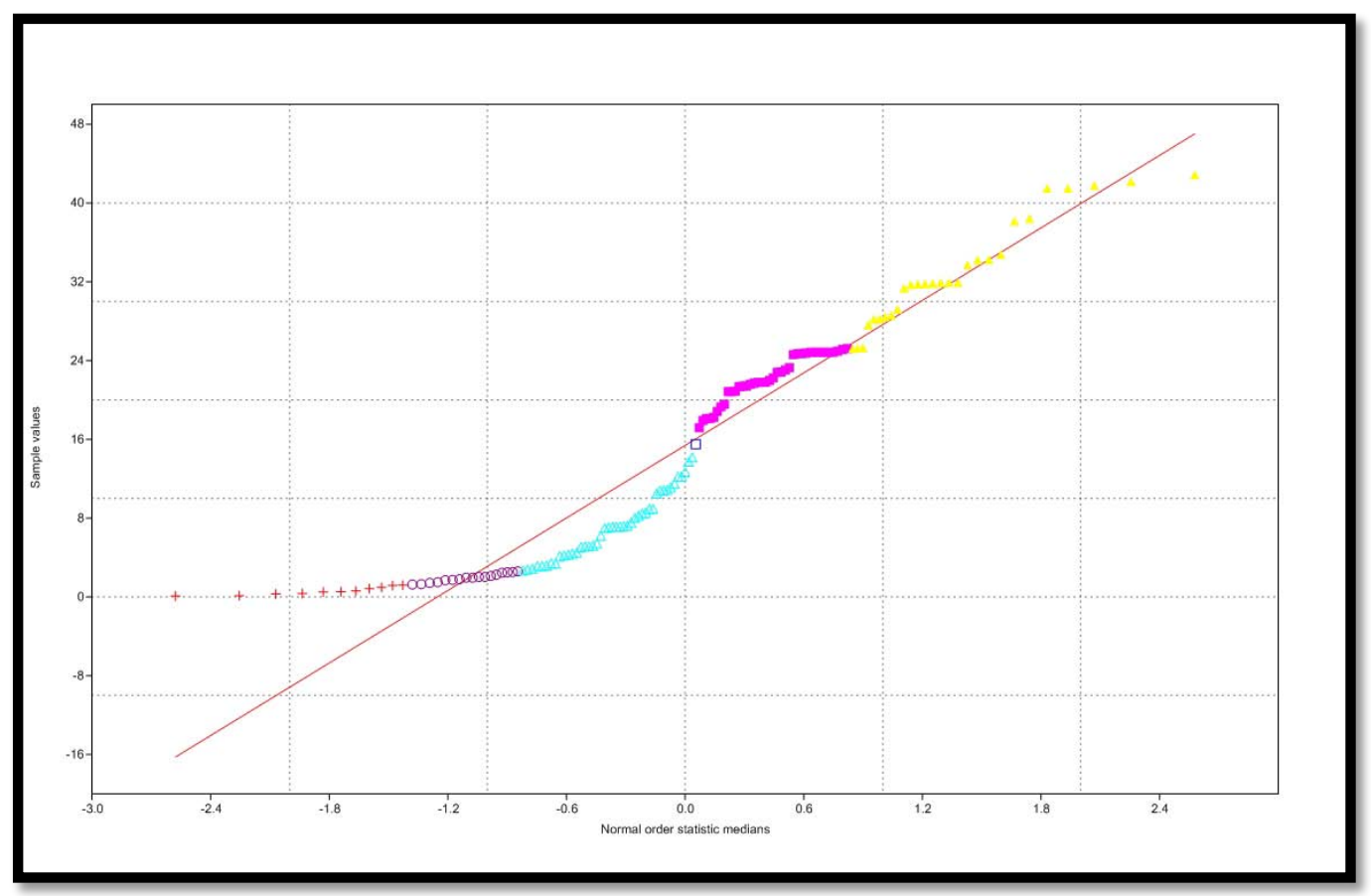

Figure 10: Normal Probability distribution of Density 


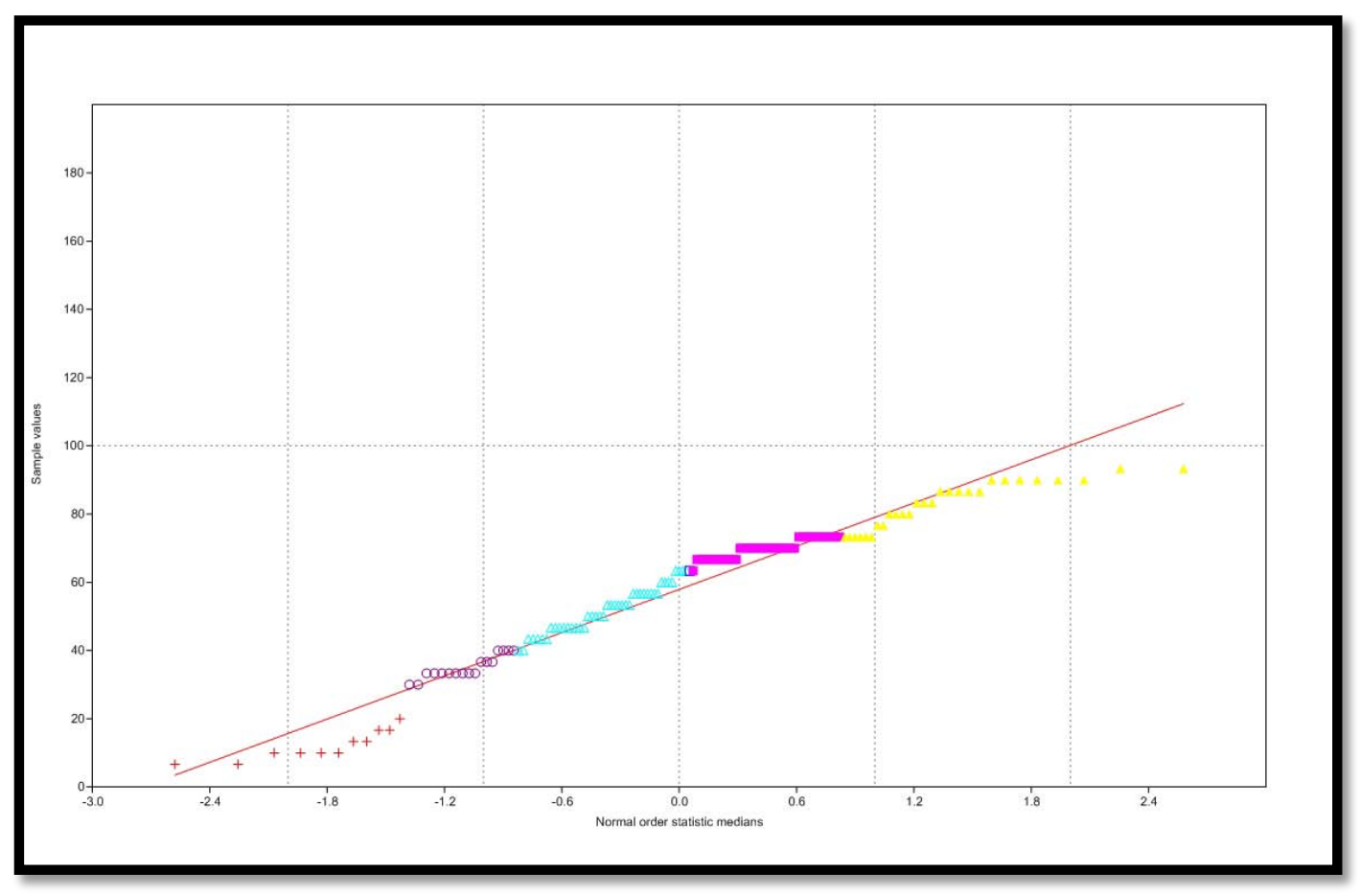

Figure 12: Matrix plot with of Number, Density and Frequency of butterfly species 


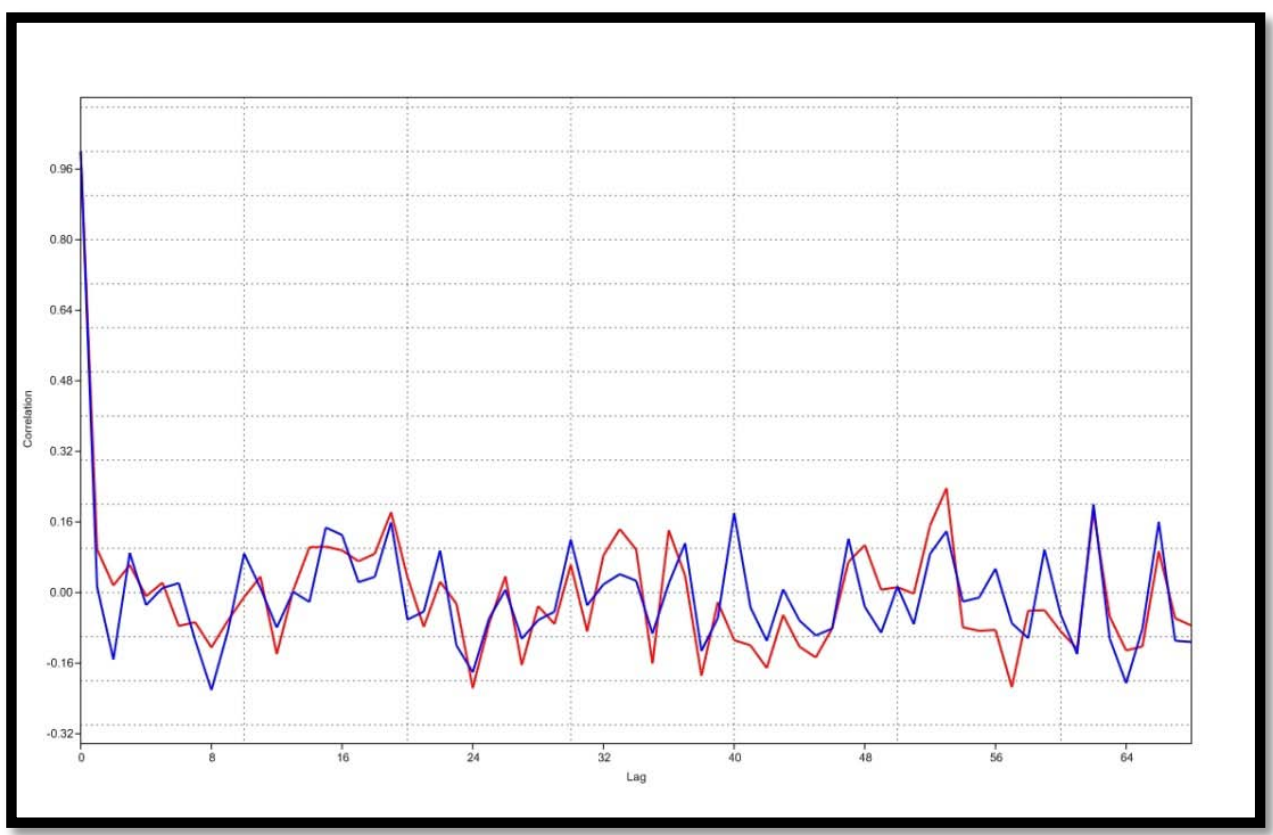

Figure 13: Density and Frequency of butterfly species showing Correlation

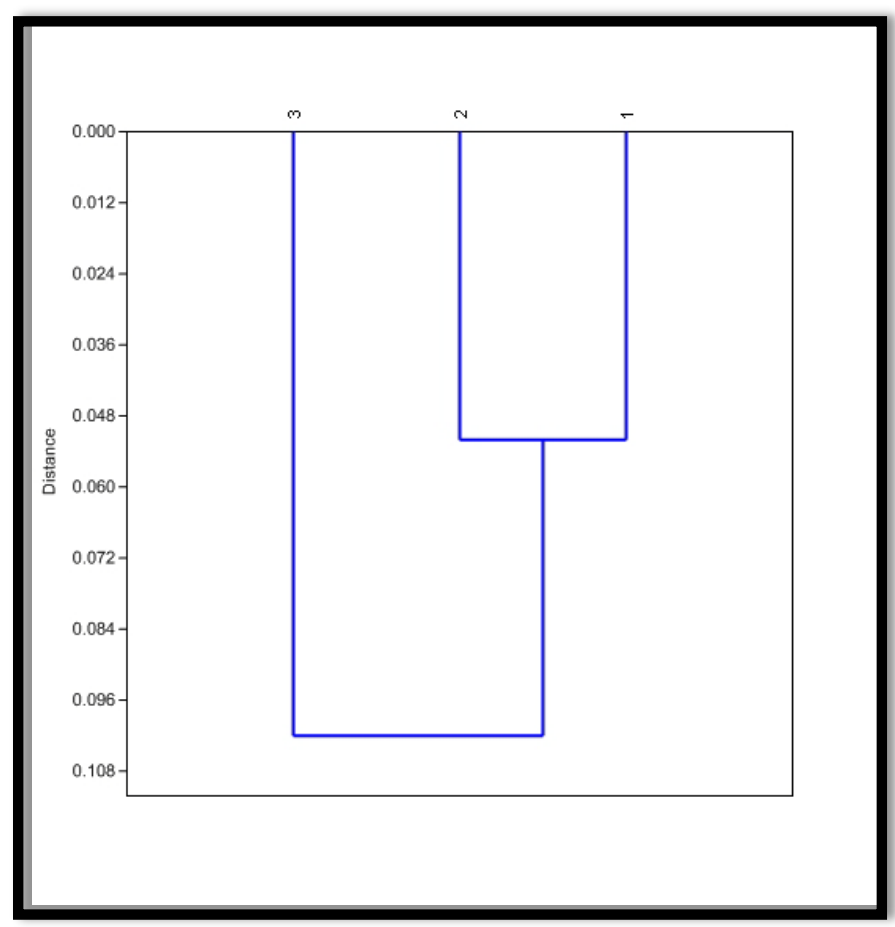

Figure 14: Cluster analysis of three districts (1: Jhargram, 2: Paschim Medinipur, 3: Purba Medinipur) on the basis of various diversity indices 

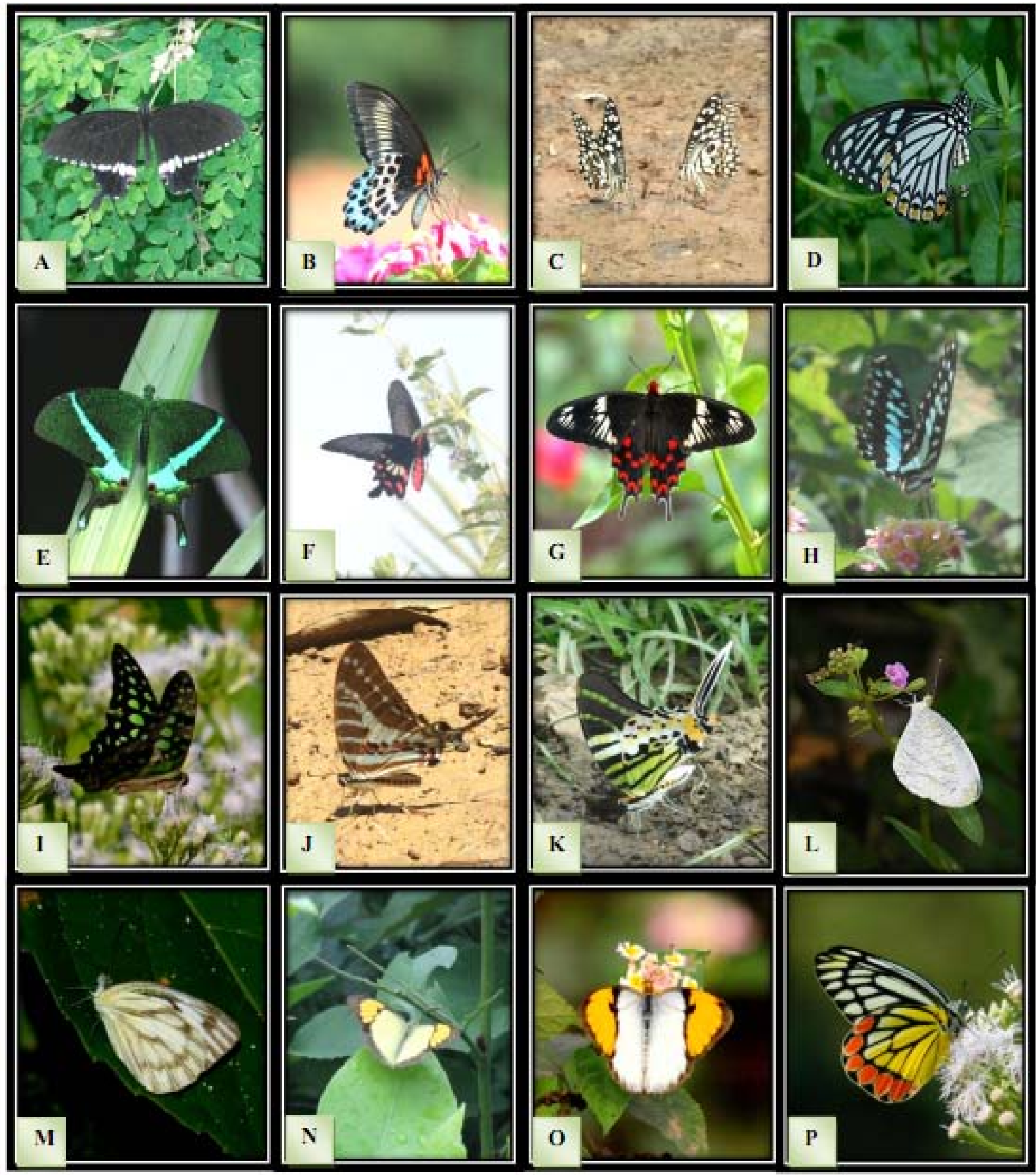

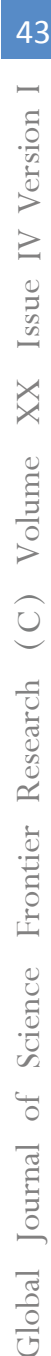

Figure 15: A) Common Mormon, B) Blue Mormon, C) Lime Butterfly, D) Common Mime, E) Common Banded Peacock, F) Common Rose, G) Crimson Rose, H) Common Jay, I) Tailed Jay, J) Spot Swordtail, K) Fivebar Swordtail, L) Psyche, M) Common Gull, N) Yellow Orange Tip, O) White Orange Tip, P) Common Jezebel 


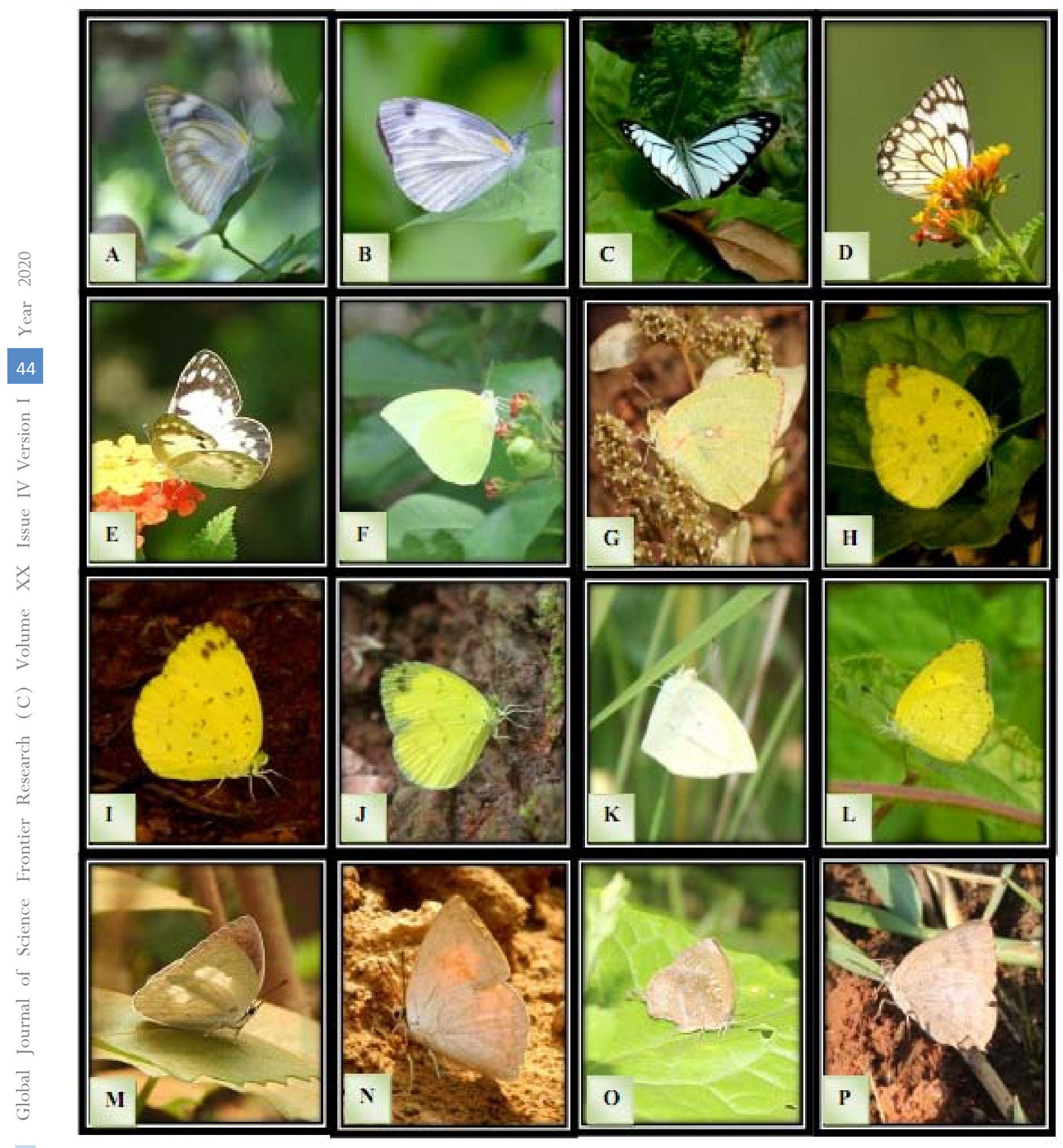

Figure 16: A) Striped Albatross, B) Indian Cabbage White, C) Common Wanderer, D) Pioneer, E) Small Salmon Arab, F) Common Emigrant, G) Mottled Emigrant, H) Common Grass Yellow, I) Three Spot Grass Yellow, J) One Spot Grass Yellow, K) Spotless Grass Yellow, L) Small Grass Yellow, M) Indian Sunbeam, N) Angled Sunbeam, O) Falcate Oakblue, P) Indian Oakblue 

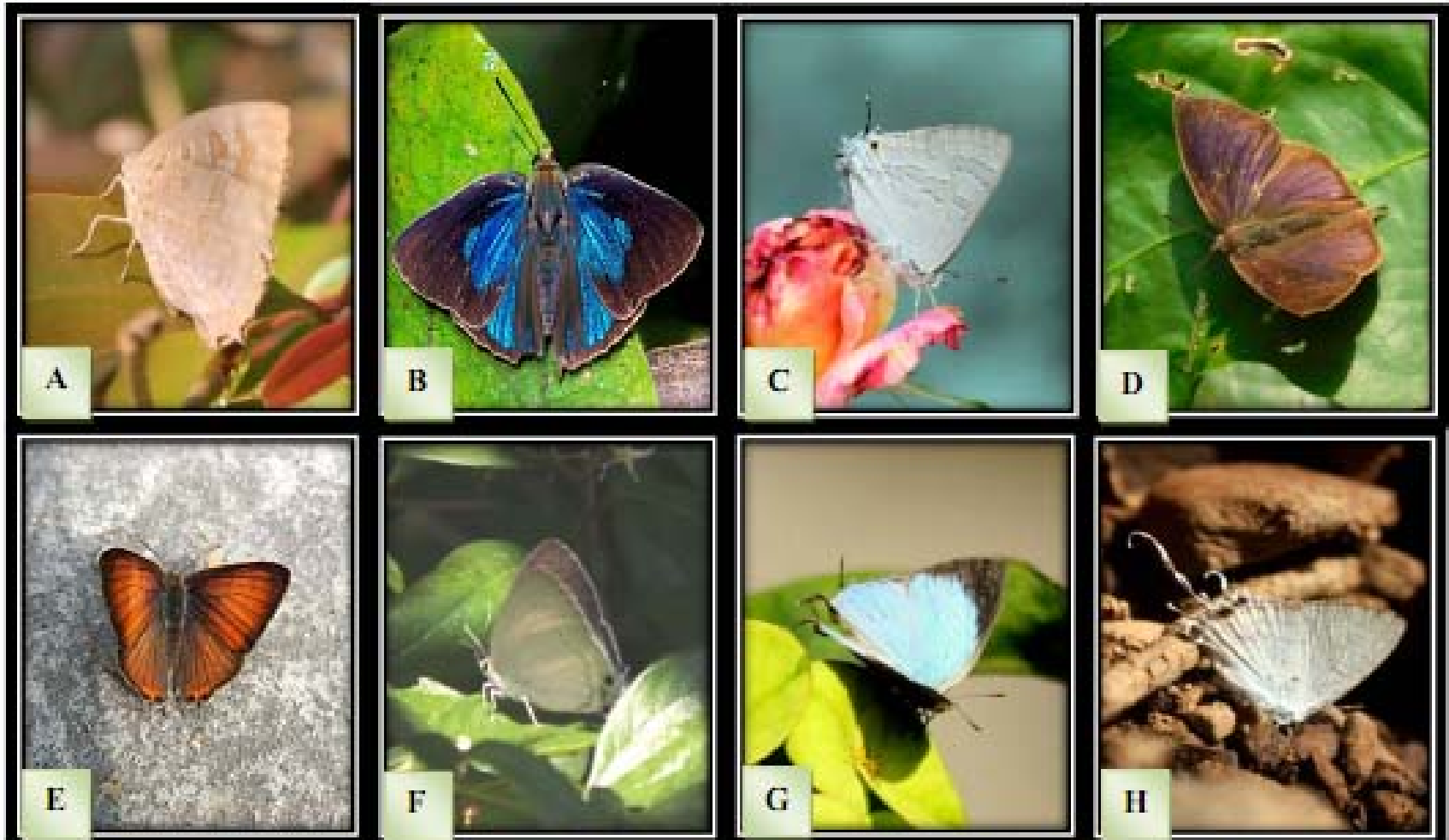

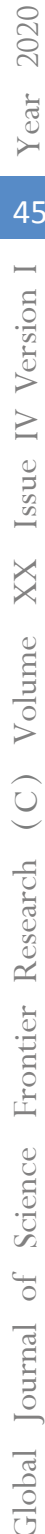
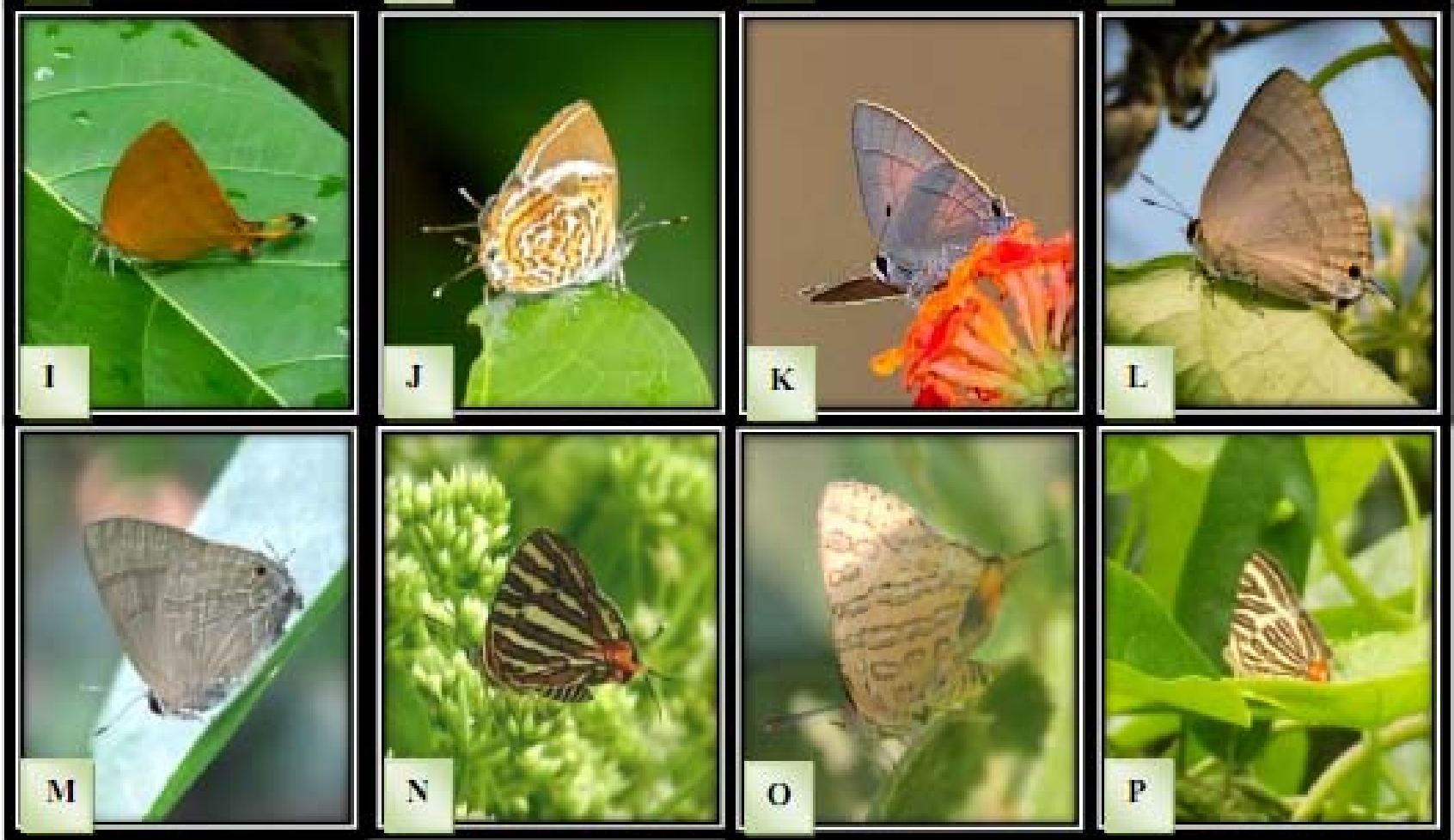

Figure 17: A) Large Oakblue, B) Silverstreak Blue, C) Common Guava Blue, D) Purple Leaf Blue, E) Redspot, F) Peacock Royal, G) Broadtail Royal, H) Fluffy Tit, I) Yamfly, J) Monkey Puzzle, K) Indian Red Flash, L) Slate Flash, M) Indigo Flash, N) Common Silverline, O) Common Shot Silverline, P) Long- banded Silverline 


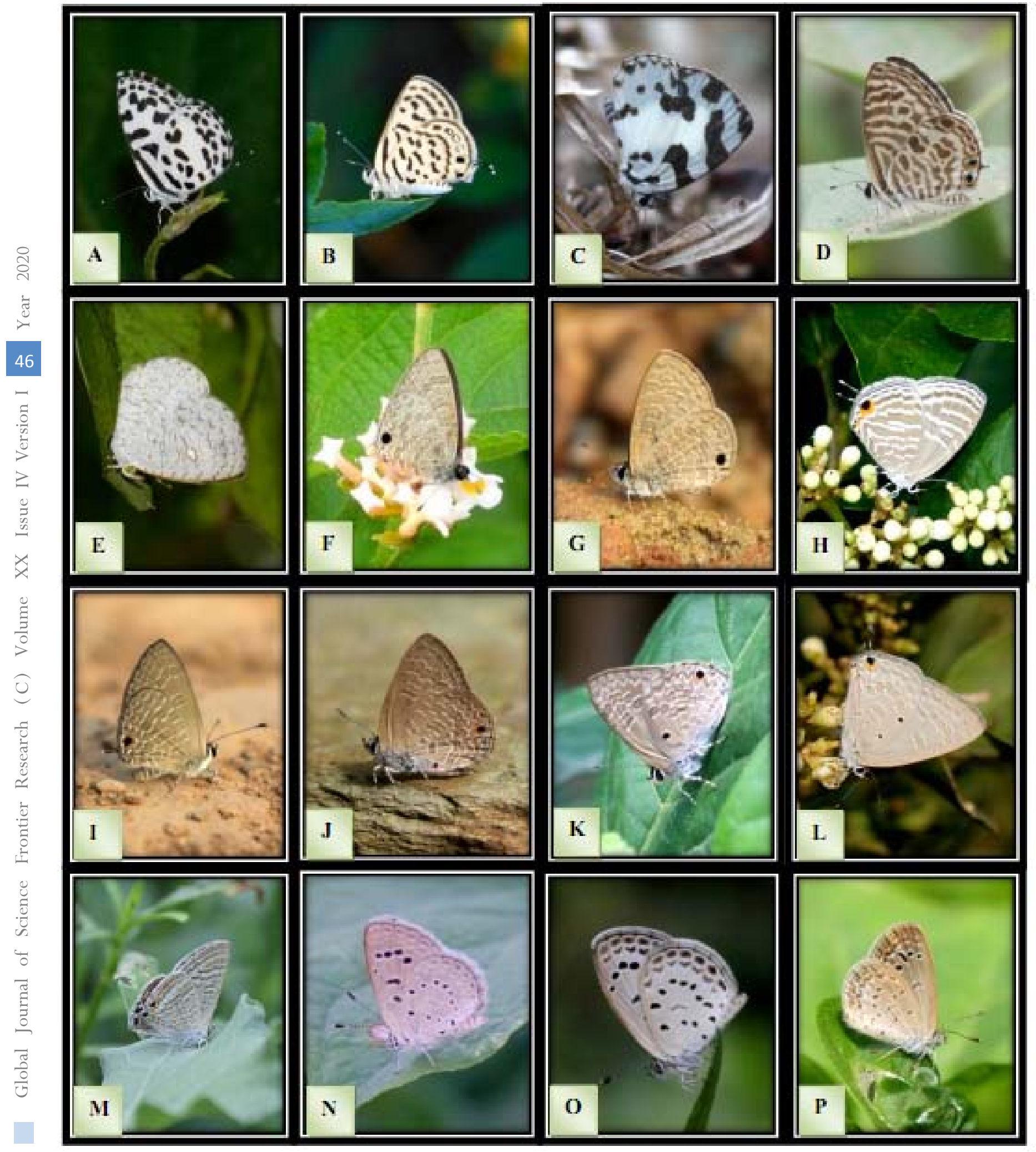

Figure 18: A) Common Pierrot, B) Tarucus sp., C) Angled Pierrot, D) Zebra Blue, E) Apefly, F) Common Lineblue, G) Tailless Lineblue, H) Common Cerulean, I) Dark Cerulean, J) Common Ciliate Blue, K) Pointed Ciliate Blue, L) Forget Me Not, M) Pea Blue, N) Dark Grass Blue, O) Pale Grass Blue, P) Lesser Grass Blue 

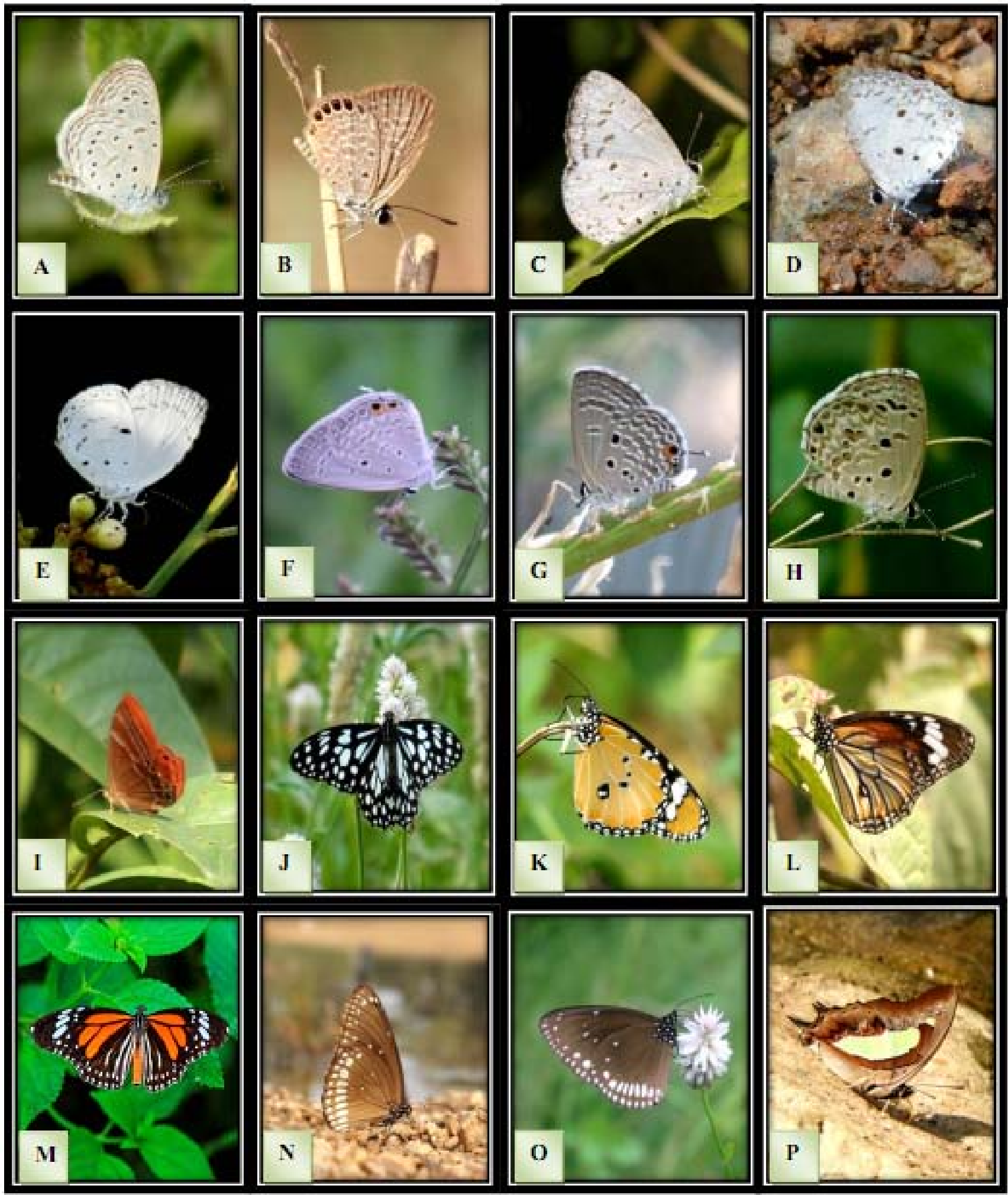

Figure 19: A) Tiny Grass Blue, B) Grass Jewel, C) Common Hedge Blue, D) Malayan, E) Quaker, F) Gram Blue, G) Plains Cupid, H) Lime Blue, I) Double-banded Judy, J) Blue Tiger, K) Plain Tiger, L) Striped Tiger, M) White Tiger, N) Common Crow, O) Brown King Crow, P) Common Nawab 

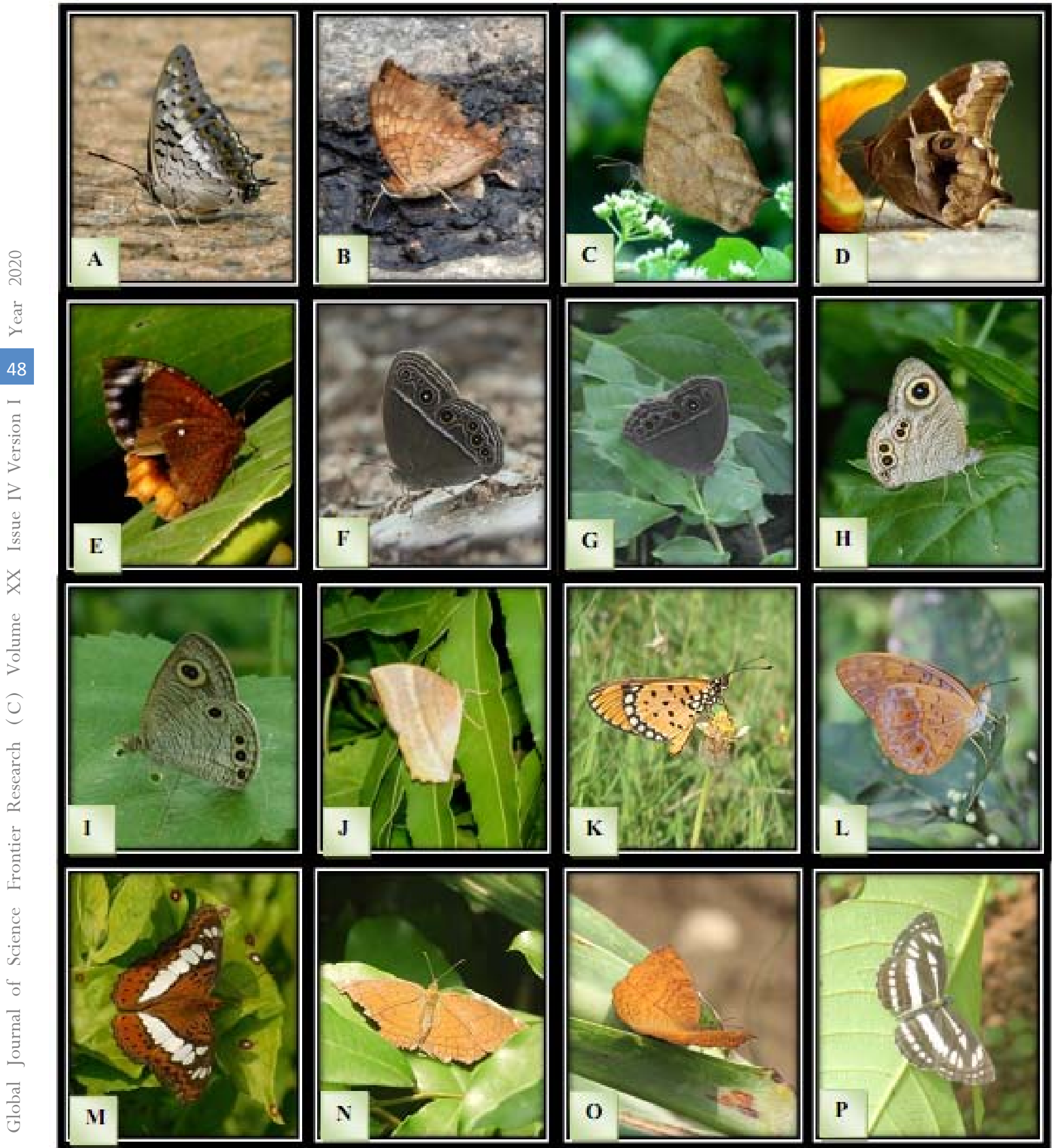

Figure 20: A) Black Rajah, B) Tawny Rajah, C) Common Evening Brown, D) Bamboo Treebrown, E) Common Palmfly, F) Common Bushbrown, G) Dark Brand Bushbrown, H) Common Five Ring, I) Common Four Ring, J) Common Duffer, K) Tawny Coster, L) Common Leopard, M) Commander, N) Angled Castor, O) Common Castor, P) Common Sailer 

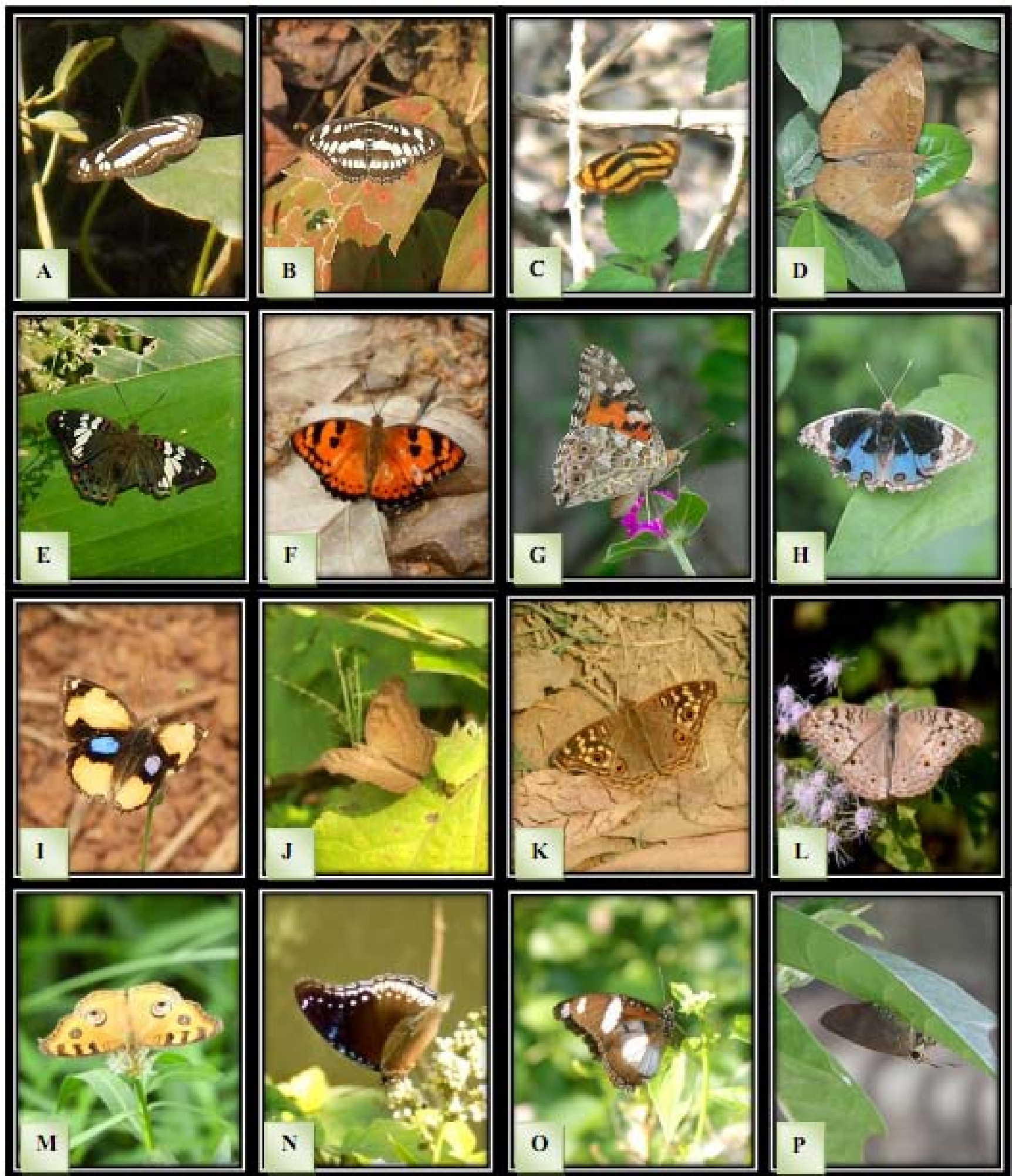

Figure 21: A) Chestnut-streaked Sailer, B) Common Sergeant, C) Common Lascar, D) Common Barron, E) Gaudy Barron, F) Baronet, G) Painted Lady, H) Blue Pansy, I) Yellow Pansy, J) Chocolate Pansy, K) Lemon Pansy, L) Grey Pansy, M) Peacock Pansy, N) Great Eggfly, O) Danaid Eggfly, P) Brown Awl 


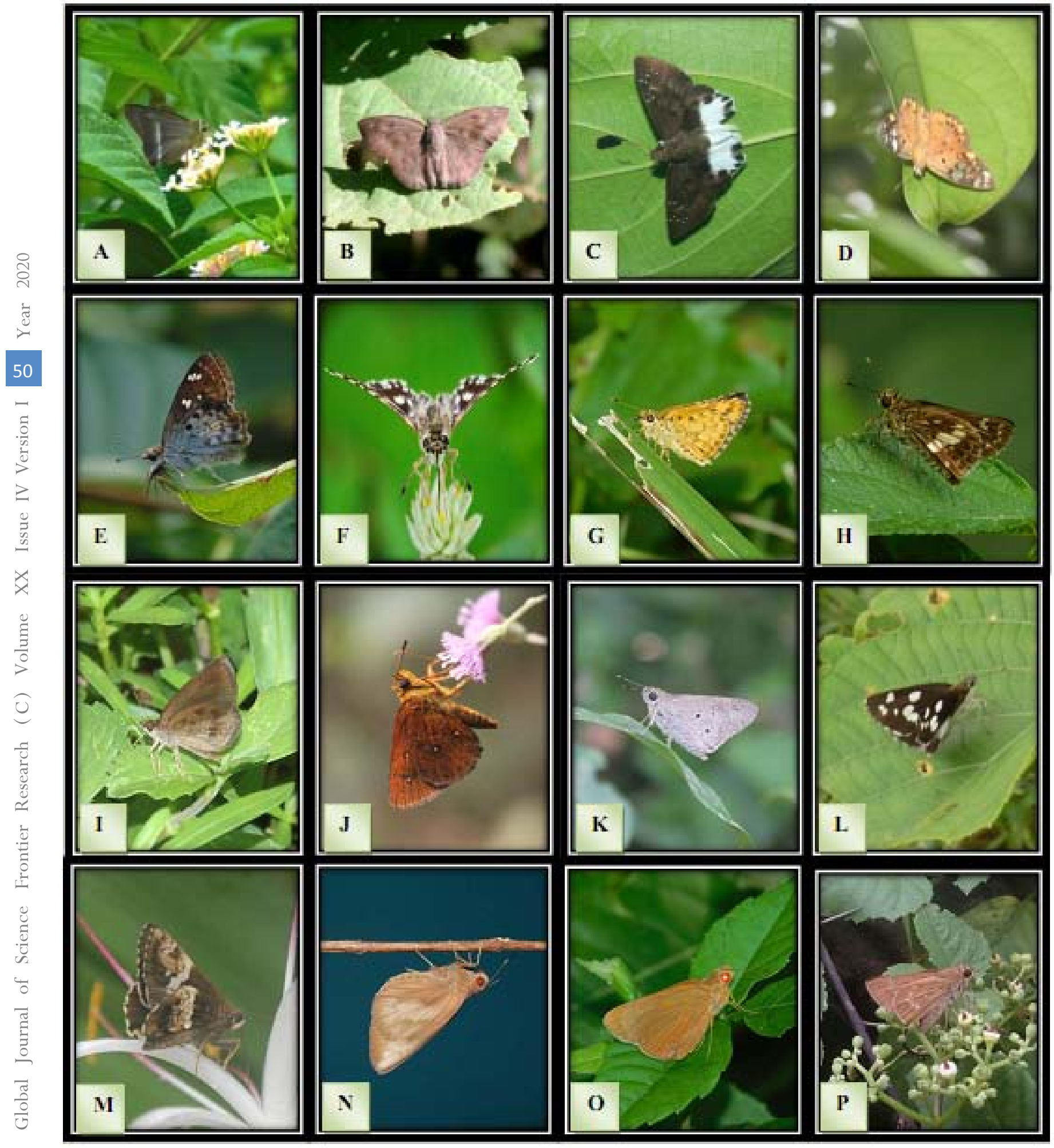

Figure 22: A) Common Banded Awl, B) Common Snow Flat, C) Water Snow Flat, D) Tricolour Pied Flat, E) Golden Angle, F) Indian Skipper, G) Bush Hopper, H) Moore's Ace, I) Forest Hopper, J) Chestnut Bob, K) Indian Palm Bob, L) Grass Demon, M) Tree Flitter, N) Banana Redeye or Banana Skipper, O) Common Red Eye, P) Ceylon Swift (Underwing) 

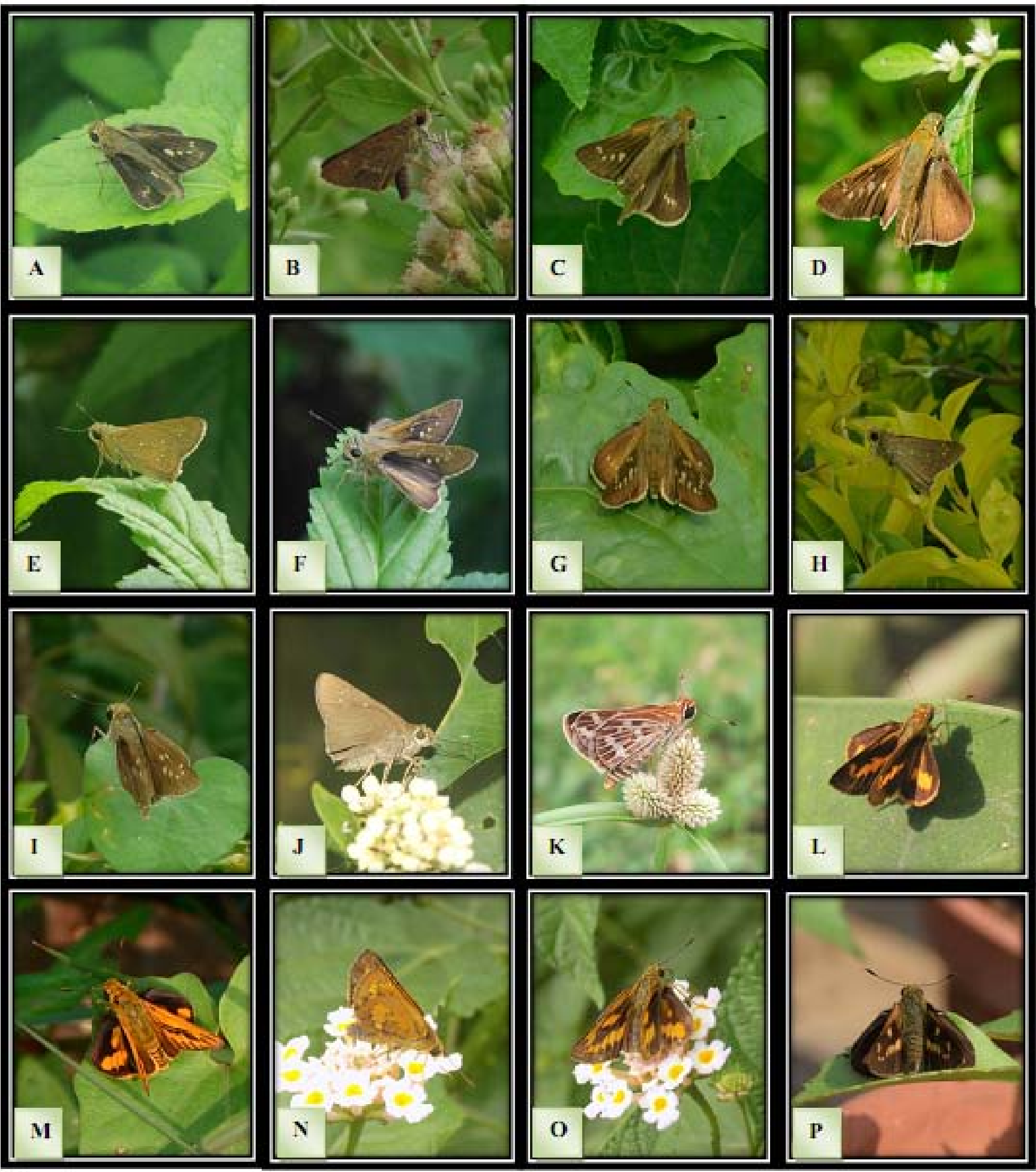

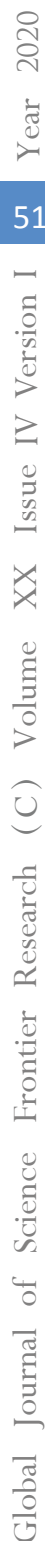

Figure 23: A) Ceylon Swift (Upperwing), B) Evan's Swift (Underwing), C) Evan's Swift (Upperwing), D) Rice Swift, E) Obscure Branded Swift (Underwing), F) Obscure Branded Swift (Upperwing), G) Conjoined Swift, H) Variable Swift (Underwing), I) Variable Swift (Upperwing), J) Paintbush Swift, K) Common Grass Dart, L) Common Dartlet, M) Common or Pale Palm Dart, N) Dark Palm Dart (Underwing), O) Dark Palm Dart (Upperwing), P) Plain Palm Dart 